\title{
Access to universal childcare and its effect on maternal employment
}

\author{
Audrey Bousselin (iD) ${ }^{1}$
}

Received: 12 November 2019 / Accepted: 14 June 2021 / Published online: 1 July 2021

(c) The Author(s), under exclusive licence to Springer Science+Business Media, LLC, part of Springer Nature 2021

\begin{abstract}
Subsidized childcare is a key instrument to support maternal employment in most OECD countries. Using a major reform implemented in Luxembourg in 2009, I study the effects of expanding access to subsidized childcare on the employment decisions of women in a context where childcare is universal and heavily subsidized, but is limited by capacity constraints. The identification strategy relies on temporal variation across age groups of children. In response to the reform, the employment rate of mothers increased by 3 percentage points, and their working time grew by $1 \mathrm{~h}$ per week. This effect hides the difference between children's ages, as mothers of the youngest children are found to be more responsive to the reform than mothers of children in primary education. Studying heterogeneous effects reveals a differential impact of the reform with regard to prior employment status.
\end{abstract}

Keywords Childcare $\cdot$ Family policy $\cdot$ Maternal employment $\cdot$ Difference-inDifferences

\section{Introduction}

In many OECD countries, access to affordable Early Childhood Education and Care (ECEC) services is recognized as a key tool to reconcile work and family life, and thus support maternal employment and reduce gender inequalities (OECD, 2018). However, empirical evidence about the effectiveness of childcare policies to support maternal employment varies according to the examined countries and time (Morrissey, 2017). Addressing this issue is of crucial importance for countries that have expanded childcare policy by increasing the amount of subsidies, the number of free

Audrey Bousselin

audrey.bousselin@liser.lu

1 Luxembourg Institute of Socio-Economic Research (LISER), 11 Porte des Sciences, L-4366 Esch-surAlzette, Luxembourg 
hours of care, or the group of eligible children. For example, between 2000 and 2013, most states in Germany adopted a free childcare policy (Felfe \& Lalive, 2018). In 2017, the UK government doubled the number of free hours of childcare for children of three to four years of age, from 15 to $30 \mathrm{~h}$ per week for working parents (Brewer et al., 2020). In 2019, Japan introduced a free daycare policy for children under the age of five (OECD, 2019). More recently, in response to the COVID-19 crisis, specific policy interventions have been set up to support working parents. These include the introduction of new childcare subsidies or special family leave, or the expansion of existing support in terms of either leave coverage or the amount of paid subsidies (Gromada et al., 2020). The extent to which public support for childcare is needed depends on the response of maternal labor supply to childcare incentives.

The current paper investigates the impact of a recent policy designed to increase the availability of affordable childcare in Luxembourg. Prior to the policy change, public childcare was universal and heavily subsidized, but offered limited places. In 2009, the government expanded the public funding of formal childcare by introducing childcare vouchers, which can be used to purchase care in both public and for-profit centers. The childcare voucher scheme aimed to increase the use of formal childcare (including before and after-school care for children attending school), helping parents to find a work-life balance and reducing socio-economic inequalities between children. Following the introduction of the revised policy, new childcare providers entered the market, increasing the overall provision of services — the number of places doubled between 2009 and 2014 (source: Ministry of Family, Ministry of Education, Luxembourg).

Employing a difference-in-differences (DiD) strategy, I estimate the effects of the policy change on maternal employment using longitudinal data from the European Union-Statistics on Income and Living Conditions (EU-SILC) survey for the period 2004-2014. The treatment group comprises women aged 20 to 50, with a youngest child up to 13 years old. As a control group, I use women in the same age group who are either childless or with a youngest child aged between 13 to 18 years old, as the trends in outcomes are very similar before the reform. I perform event-type studies and tests on pre-reform differences in slopes to ensure that eligible and non-eligible mothers can be compared. In a second step, I also exploit the differences in the intensity of the policy change between children's age over time, as the increase in the number of places at childcare facilities was more pronounced for younger than for older children.

This setting has many interesting features. First, it allows me to provide evidence concerning the effects of expanding existing childcare subsidies, whereas a great deal of previous literature focuses on the role of the introduction of childcare subsidies or preschool programs for children up to three years of age. The previously published results may not be transferable to a case where existing childcare subsidies are expanded for different reasons. On the one hand, the contexts of maternal employment and childcare attendance are different. It is likely that the group of women who may be sensitive to the incentives given by childcare policies differs from the group of women who may respond to the introduction of such a policy. On the other hand, the effects found for parents of preschool children may be different to those found for parents of younger children, mainly because preferences for childcare arrangements vary with the age of the child (Leibowitz et al., 1988). Second, the childcare voucher scheme introduced in Luxembourg benefits all children, regardless of the family's income and the parents' employment status. While most of the existing evidence relies on programs 
under which childcare subsidies are conditional on income or employment and/or focusing on mothers of preschool children, I have been able to analyze the effects of the policy on the overall population. This could be of great interest to policymakers.

The results indicate that the likelihood of employment for women with at least one child under 13 increased by 3 percentage points (baseline 0.60 ) and the hours of work (including for those who were not working before the reform) increased by around $1 \mathrm{~h}$ per week (baseline 17.65 h). The effect of the reform hides the difference between children's ages, as mothers of the youngest children are found to be more responsive to the reform than mothers of children in primary education. There is also evidence of heterogeneous responses by prior employment status. The results confirm that in a context where the employment of mothers and daycare attendance are low, making affordable childcare more widely available is a way to increase maternal employment. Nevertheless, a rough calculation suggests a 0.17 percentage point increase in the employment rate of mothers of a child aged $0-12$, for a 1 percent increase in the daycare attendance rate. This actually suggests a relatively modest effect of the reform.

The paper is laid out as follows. Section 2 provides a brief overview of the related literature. In Section 3, I then describe the institutional context and the 2009 childcare reform. Section 4 and Section 5 respectively present the data and identification strategy. The results, including robustness checks, are presented and discussed in Section 6. Lastly, I conclude in Section 7.

\section{Related literature}

This paper relates to a large body of literature in economics investigating the impact of the provision of subsidized childcare on maternal employment (see Morrissey, 2017 for a review). For mothers, inadequate provision of affordable childcare services may lead to them withdrawing from the labor market, with negative effects on future earnings potential. ${ }^{1}$ The most recent papers exploit policy changes that provide exogenous variations in prices or in access to childcare, with the aim of identifying the impact of lower childcare prices or greater access to outside household childcare on child and maternal outcomes. Most studies focus on preschool children (3-6 years old) and provide mixed empirical evidence. Some authors find a positive and sizable effect of public childcare on maternal employment (Keane, 1995; Baker et al., 2008; Berlinski \& Galiani, 2007; Lefebvre \& Merrigan, 2008; Herbst, 2017; Cascio, 2009; Lefebvre et al., 2009; Nollenberger \& Rodriguez-Planas, 2015). By contrast, others report small, if any, effects for specific subgroups, such as single mothers or the lower-educated (Gelbach, 2002; Fitzpatrick, 2010, 2012; Goux \& Maurin, 2010; Hardoy \& Pal, 2015; Felfe et al., 2015; Givord \& Marbot, 2015). Small effects are found when a reform leads only to marginal decreases in the costs of childcare (Lundin et al., 2008) in contexts where female employment and childcare attendance are already high, simply because the scope for policies is limited. Small to no effects are also found if newly subsidized places crowd out existing private childcare

\footnotetext{
1 In this regard, there is already a great deal of evidence documenting the cost of motherhood on women's careers (Waldfogel, 1998; Lundberg \& Rose, 2000; Sigle-Rushton \& Waldfogel, 2007; Fitzenberger et al., 2013; Goldin, 2014; Angelov et al., 2016; Adda et al., 2017; Blau \& Winkler, 2017; Rossin-Slater, 2018).
} 
arrangements, especially when there is still rationing after expansion (Bauernschuster et al., 2016; Cascio et al., 2015; Cattan, 2016; Busse \& Gathmann, 2018). From a policy perspective, providing evidence about the role of policies that expand subsidized childcare is important, as supporting female employment is a key policy goal in most OECD countries and the amount of public funding devoted to childcare interventions is growing (OECD, 2018).

It is also important at the time of the COVID-19 pandemic, when some OECD countries have put in place temporary support for working parents, while recent evidence also shows that women's labor force attachment tends to be more affected than that of men (Croda \& Grossbard, 2021).

In addition, my analysis is related to literature concerning the effects of government vouchers on the public provision of private childcare services. Proponents of using vouchers in the childcare market argue that such a scheme may increase parents' choices, and thus their satisfaction. Voucher systems may also increase the quality of childcare by stimulating competition between providers (Bradford \& Shaviro, 1999; Steuerle, 2000). However, in a context of universally subsidized childcare, a voucher scheme may lead to non-negligible crowding out effects, as the new arrangement may substitute for private alternatives (Bergstrom et al., 1986). There is empirical evidence that voucher schemes increase the use of for-profit daycare by increasing demand for childcare and encouraging new (for-profit) providers to enter the market (Bassok et al., 2014; Warner \& Gradus, 2009). This effect is found to be higher in areas that suffered from rationing before the introduction of a voucher scheme (Viitanen, 2011). The current paper provides additional evidence about this issue, by investigating the effects of childcare vouchers on parental choice in a context of universal public childcare with excess demand prior to a reform.

\section{The institutional context and the 2009 childcare reform}

In this section, I describe the institutional context in Luxembourg to underline the extent to which my results could be relevant for other countries, before detailing the 2009 reform in question.

In Luxembourg, as in other OECD countries, employment rates are lowest for mothers of children below the age of three, those with a low education level, and those with a migration background (Source: OECD family database). To support working parents, Luxembourg provides paid maternity and parental leave, as well as subsidized, high-quality public childcare. Paid maternity leave lasts for 16 weeks, of which eight must be taken by the mother before childbirth. On completion of maternity leave, working parents may apply for parental leave. ${ }^{2}$ With regard to the childcare system, two types of care arrangements can be distinguished. A childcare

\footnotetext{
${ }^{2}$ Up to 2016, parental leave consisted of 6 months full-time leave or 12 months part-time leave for the eligible parent. Eligible people were parents of children born after 1 January 1999, who were employees linked to the national social security system. An eligible parent was entitled to a monthly flat-rate benefit: 1178.31 euros for full-time leave or 889.15 euros for part-time leave. By comparison, the minimum wage in Luxembourg was 1700 euros per month in 2009 at the time the childcare voucher was created. Parental leave was mainly taken by mothers: the take-up rate was $46 \%$ among mothers compared with $11 \%$ among fathers (Valentova, 2019).
} 
center refers to all childcare provided on a full-time or part-time basis outside the parental home in licensed establishments. There is no legal right to be given a place. Family daycare is provided in a setting that is generally a childminder's home. Childcare centers and family daycare must satisfy a set of criteria established by law. These criteria relate to the structural quality of the care, including the staff-to-child ratio, the group size, the education and training of the employees, and the characteristics of the facilities. Both childcare centers and home-based care provide before and after-school care for children attending education. Compulsory schooling starts at the age of four in Luxembourg and most children start secondary school when they turn 12. At the age of three, children can enter preschool (Precoce), which is not mandatory and is provided on a part-time basis by municipalities. Around the year of the reform, two-thirds of eligible children were in a Precoce class (source: Ministry of Education, Luxembourg).

Childcare centers can be either publicly or privately owned. Before the 2009 reform, the price paid by parents in public centers depended on the household income and household composition, with lower prices for large families and those on a low income. By contrast, private centers and family daycare were free to set their own prices, and parents did not benefit from subsidies. Childcare provision rates for children under the age of three were low for many years in Luxembourg-in fact below the 33 percent target agreed at the 2002 Barcelona Summit. ${ }^{3}$ This can be explained by the comparatively greater demand for public childcare centers, which were more attractive than the private equivalents because, on average, the former provided childcare at a lower price and at a similar (or even higher) quality.

In 2009, the government passed the childcare reform legislation, the so-called childcare voucher, to promote access to affordable childcare services, help parents to find a work-life balance, and reduce socio-economic inequalities between children (Journal Officiel G-D Luxembourg, 2009). All children under 13 years old or who are not yet enrolled in secondary education are eligible. Under the new policy, all types of formal childcare arrangements are subsidized (public and for-profit centers, as well as family daycare), which is a distinct shift from the previous government policy of only subsidizing public centers. Providers need to register for the childcare voucher system, and this implies that they must meet particular quality requirements. Beyond the structural quality requirements already regulated before the reform, providers must now follow a national curriculum that defines guidelines on the process quality (e.g., the quality of interactions between children and caregivers) and the educational content of the care. With the new policy, providers receive direct funding from the government and the amount paid by parents is calculated by taking

\footnotetext{
3 The Barcelona European Council held in 2002 set objectives with regard to the availability of high quality and affordable childcare facilities for preschool children, through two targets known as the Barcelona targets: "Member states should remove disincentives to female labour force participation and strive, taking into account the demand for childcare facilities and in line with national patterns of provision, to provide childcare by 2010: to $90 \%$ of children from age 3 until mandatory school age; and to $33 \%$ of children under 3 years of age" (European Union, 2010). There were waiting lists (Bousselin, 2015), as childcare centers used priority rules to allocate the available places among applicants. While in the public sector, priority rules were derived from family characteristics, in the for-profit sector, the available places were allocated according to the "first come, first served" principle. In 2007, 61\% of public childcare facilities refused children because of the limited numbers of places, compared with $29 \%$ of private childcare centers (Bousselin, 2017).
} 
Table 1 Childcare costs (in euros per month for a fulltime place)

\begin{tabular}{lllll}
\hline & \multicolumn{4}{l}{ Children aged: } \\
\cline { 2 - 6 } & $0-3$ & $4-5$ & $6-12$ & Together \\
\hline Total cost & 1017 & 570 & 461 & 663 \\
Amount paid by the parents & 270 & 123 & 91 & 156 \\
Amount paid by the government & 747 & 447 & 370 & 507 \\
$\%$ of the total cost paid by the & $28 \%$ & $24 \%$ & $24 \%$ & $25 \%$ \\
parents & & & & \\
\hline
\end{tabular}

Source: Annual reports (years 2009-2012), Ministry of Family and Integration, Luxembourg

into account the household's income, the size of the family, and the number of hours of care. The reform has led to substantial price reductions, as on average 75 percent of the full price is paid by the government (see Table 1). Before the reform, the average hourly price was 2.50 euros in the public sector and 4.90 euros in the forprofit sector, compared with 1.40 euros in both sectors after the reform (Ministry of Family and Integration 2004-2012). ${ }^{4}$

The new policy has given a huge boost for new providers to enter the market. This is not surprising, as before the reform, the childcare sector was bound by capacity constraints, and the number of families that could afford formal childcare increased following the policy change. The increase has been more pronounced in the private sector: between 2008 and 2011, the number of private centers and family care doubled, while the number of public centers grew by 20 percent (see Table 2). The number of places also increased to a much greater extent for younger children than for older ones: the number of places for children aged 0-3 multiplied by 3.6; those for children aged 4-12 years old by 1.6. This translates into a growth in childcare attendance. There has been little change in the composition of attendance (see Fig. 1), suggesting that new places in childcare centers have been occupied by children who were cared for by their parents before the reform.

Due to the rise in subsidies and in attendance, the government expenditure on early childhood education and care rose from 0.42 percent of GDP in 2009 to 0.77 percent in 2013 (source: OECD Family Database). The budget devoted to the childcare policy tripled over the period, growing from 87 million euros in 2009 to 303 million in 2015, which is now roughly half of public spending for family allowances (source: Ministry of Education and National Fund for Family Allowances).

\section{Data}

I use data from the Luxembourg household panel survey (EU-SILC/PSELL 3). This is an annual survey of the population in Luxembourg, and the Luxembourg component of the European Union-Statistics on Income and Living Conditions (EUSILC). This survey collects timely and comparable cross-sectional and longitudinal

\footnotetext{
${ }^{4}$ One euro was equal to 1.2 United States dollars in January 2021.
} 
Table 2 Number of childcare providers and number of places in Luxembourg over the period 2008-2011

\begin{tabular}{cllll}
\hline & 2008 & 2009 & 2010 & 2011 \\
\hline $\begin{array}{c}\text { Number of providers } \\
\text { Public childcare center }\end{array}$ & 330 & 350 & 376 & 397 \\
$\quad$ Private childcare center & 93 & 113 & 176 & 222 \\
$\quad$ Family care & 272 & 368 & 463 & 555 \\
Number of places by age group & & & & \\
0-3 years old & 2381 & 3986 & 5467 & 8636 \\
4-12 years old & 16,471 & 19,056 & 25,735 & 27,401 \\
Total & 18,852 & 23,107 & 30,202 & 36,037 \\
\hline
\end{tabular}

"Childcare centers" refer to all childcare provided outside parental homes in licensed centers, which can be publicly or privately owned. "Family care" refers to care provided in a home setting, generally a childminder's home. Source: Annual reports (years 2009-2012), Ministry of Family and Integration, Luxembourg

multidimensional microdata on income, poverty, social exclusion, and living conditions. Social exclusion and housing information are collected at the household level, whereas labor, education, income, and health data are collected at the individual level. The survey has been used to provide data on and monitor social inclusion and poverty in the European Union. ${ }^{5}$ The Luxembourg survey data is representative of the whole population living in the country and linked to the national social insurance scheme. The main advantage of the EU-SILC/PSELL 3 survey for my analysis is that it contains detailed information covering parents as well as children. This allows me to match women with their partner and their child(ren), and thus to identify families. Another advantage of this data for my analysis is that it provides five years of pre-reform data and four years of post-reform data, enabling me to perform event-type studies and placebo tests (see Section 6). I use the waves 2004-2014, but exclude data from 2003 because the definition of childcare arrangements is different from the other waves. I selected women aged 20 to 50, and the final sample comprises 34,287 women.

\subsection{Outcome variables}

In the survey, individuals report their employment status over the year and, if they are working, the number of hours of work. I take the most frequent status over the year to define an individual's employment status, and also use this information to build a dummy variable for whether a person is employed. "Employed" covers fulltime or part-time employment, including maternity leave and parental leave. In the survey, the working hours are by definition only reported by those in the labor market. I include a zero hours figure for mothers who do not work in order to avoid composition change when estimating the effect of the reform on the number of hours of work (Angrist \& Pischke, 2009). Related to any change in mother's labor supply,

\footnotetext{
${ }^{5}$ For more information on the EU-SILC survey, see https://ec.europa.eu/eurostat/web/microdata/europea n-union-statistics-on-income-and-living-conditions.
} 

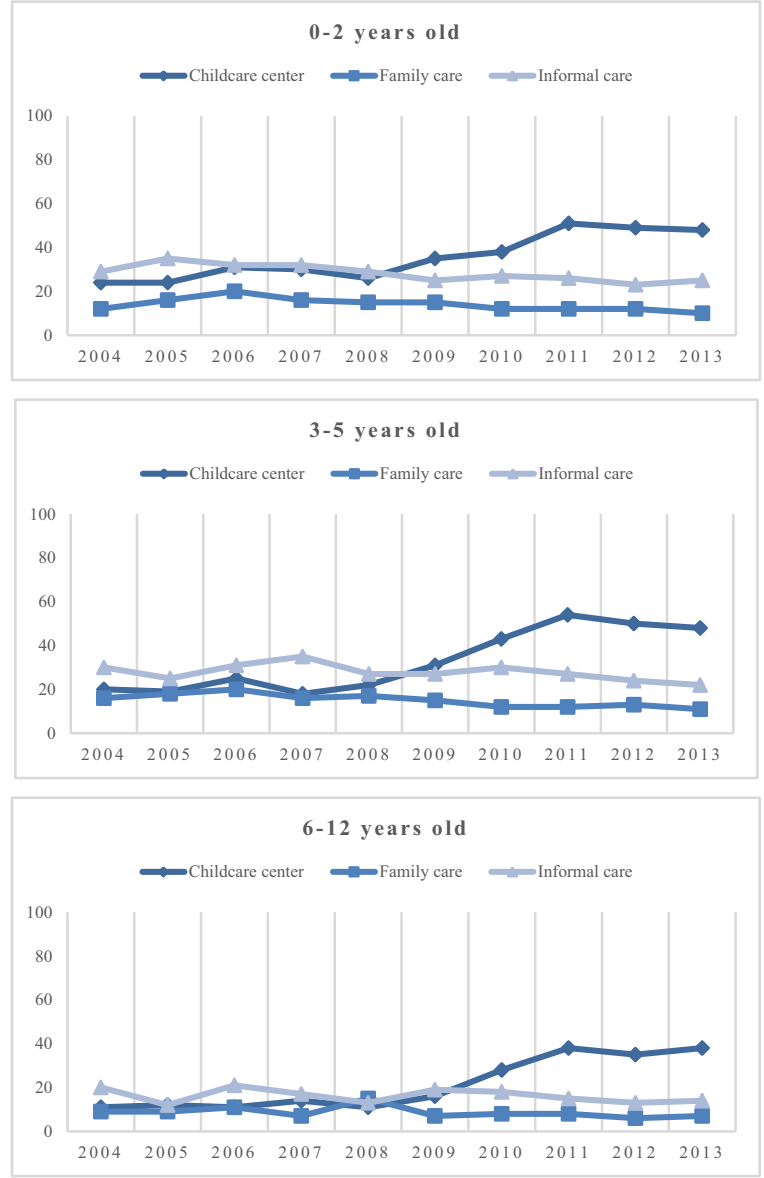

Fig. 1 Attendance rate over time by childcare arrangements and by children's age. Attendance rate is calculated as the percentage of children cared for. Source: EU-SILC-PSELL 3. Statistics are weighted using individual weights

one can expect change in fathers' labor supply. In a similar way as for mothers, I also investigate the effects of the reform on the employment and hours of work of fathers.

\subsection{Control variables}

I use the age of the mother and a set of three dummies for the level of education, with the omitted category being the lower level of education. For marital status, I define a dummy variable for being a single mother. Due to the limited number of cases, I am not able to distinguish between married mothers and those who were cohabiting, and I therefore refer to married and non-married cohabiting mothers interchangeably throughout the remainder of the paper. As non-natives comprise an important proportion of the population in Luxembourg, I use the date of arrival in the country to make a distinction between non-natives who arrived as a child and those who arrived 
as an adult. I assume that the first subgroup is more likely to have migrated with their parents and thus to have had more opportunity to rely on their parents (or extended family) for informal care compared with the latter group. It may also be the case that norms regarding maternal employment and non-maternal childcare differ with respect to the time spent in the host country. I thus use a set of three dummies for the migration background: native (the omitted category), non-native arrived as a child, and non-native arrived as an adult.

\subsection{Descriptive statistics}

Table 9 in the appendix provides a summary of the descriptive statistics for the whole sample separately for the pre-reform period and the post-reform period. The employment rate of women with a youngest child of under 13 increased by 6 percentage points between the pre-reform (2004-2008) and post-reform (2009-2014) period. This was accompanied by an increase in the hours of work (2.05 per week) and an increase in the incidence of part-time working among those employed (3 percentage points). Similarly to the whole population in Luxembourg, the proportion of non-natives is high among the group of mothers with a youngest child of under 13 years old: before the reform, almost half of them were non-native, though the figure only slightly increased after it. Comparing the situation before and after the reform shows no significant changes in the level of education, or the age of the partner and their likelihood of being in work. The employment probability of mothers with a youngest child of aged 13 or above increased over the period (4 percentage points). The hours of work also slightly increased (less than $1 \mathrm{~h}$ per week), as did the incidence of part-time work (7 percentage points). The post-reform sample is slightly older than the pre-reform one. For those in a couple, the employment likelihood of the partner decreased ( 2 percentage points), although this is unsurprising given that the sample is becoming older and employment decreases with age.

\section{Identification strategy}

In the current paper, I make use of a large reform in Luxembourg that provided an exogenous change to the overall provision of subsidized childcare. The reform was announced in autumn 2008 and implemented rapidly (on March 1, 2009). It is plausible to assume that most families were not sufficiently familiar with the reform early enough for it to lead to ex-ante behavior in reaction to the policy. In addition, new facilities needed time to establish and open. I accordingly expect that most of the effect triggered by the reform took place after its implementation. To identify the impact of the childcare reform on the employment decisions of women, I exploit the differential provision between the age of children over time in a standard differencein-differences (DiD) model. To estimate the effect of the reform, I compare the change in outcomes of those affected by the reform (the treatment group) before and after it, using the change in outcomes of those unaffected by the reform (the control group) to control for common-trend effects. The parents affected by the change in the provision of subsidized places were those whose youngest child was under 13 years old at the time. The change in the provision of subsidized places differs with regard 
to children's age, and as explained in Section 3, the increase in the provision of subsidized places was much more pronounced for children under three years of age than for older ones. I use the difference between children's age over time to investigate heterogeneous response concerning the intensity of the treatment. I split the treatment group into three subgroups based on the age of the youngest child: mothers with a youngest child of 0-2 years old, mothers with a youngest child of 3-5 years old, and mothers with a youngest child of 6-12 years old. The control group comprises mothers with a youngest child of 13-18 years old: they would not benefit from the reform, but are otherwise similar to the treated mothers. Women without a child, who would also not be affected by the reform, comprise another control group for a sensitivity analysis.

I use the years 2004-2008 as the pre-treatment years and 2009-2014 as the posttreatment years. The model is shown by Eq. (1):

$$
Y_{i t}=\alpha+\beta_{1}\left(\text { Treat }_{i} \times \text { Post }_{t}\right)+\beta_{2} \text { Treat }_{i}+\gamma X_{i}+\theta \text { Year }_{t}+\varepsilon_{i t}
$$

where $Y_{i t}$ is the outcome of interest for individual $i$ in year $t$, Treat $t_{i}$ is a dummy variable that defines the treatment group, and Post $t_{t}$ is a dummy variable equal to 1 in the post reform period. The interaction term $\left(\right.$ Treat $_{i} \times$ Post $\left._{t}\right)$ enables me to derive an estimate of $\beta_{1}$, which is the coefficient of interest for the childcare policy impact. $X_{i}$ is a vector of individual and household covariates to control for differences between the treatment and the control groups. I use age, education level, migration background, and the number of children in the household, as all these characteristics are important determinants of external childcare and employment decisions. Year ${ }_{t}$ is a vector of year dummies to account for time-varying patterns in the outcomes (Bertrand et al., 2004). $\alpha$ is a constant and $\varepsilon_{i t}$ is an error term.

The key identifying assumption of the model is that the difference in outcomes between the treated group mothers and the control group mothers would have remained constant in the absence of the reform. This means I assume there are no unobserved characteristics that might have changed over time and affected, in a different way, the outcomes of the treatment group compared with the outcomes of the control group. This assumption cannot be tested. However, I take advantage of the panel nature of the data to check whether the treatment and control mothers show similar trends for the years preceding the reform. I perform event-type studies in the next section and check the plausibility of the common trend assumption by means of placebo tests and a test of differences in slopes' outcomes in the pre-reform period. All the results are reassuring. There is difference in the initial levels of employment between the treated and the control groups of women (see Table 9 in the appendix) that can be explained by a factor that has no impact on employment trends. Preferences for childcare vary with children's age, and can explain the difference in initial levels of employment according to the age of the youngest child. In Luxembourg, the traditional view of gender roles still prevails in some families: maternal childcare is perceived as the best option for toddlers, therefore maternal employment is not desirable when children are very young (Valentova, 2015). Preferences for maternal care for toddlers may explain the difference in the original levels of employment of the treated and control groups, but this would not affect the trends. Another threat to identification relates to other policies that could influence the outcome variables for the treatment or control group (differently). Of particular 
concern is the economic downturn of 2007-2008 that took place just before the reform. After 2008, the Luxembourg government introduced policy measures to help alleviate the effects of the economic crisis (Matha et al., 2016). These policies, which included employment support, were large scale. It thus seems reasonable to believe that women in the treated and in the control groups were equally exposed to the policies. In addition, the reform might have affected mothers' work and childcare decisions before its actual implementation (ex-ante responses). Given that the reform was enacted quickly after its announcement and that there were capacity constraints, there appears little scope for ex-ante responses. Lastly, the common trend assumption may be violated if the characteristics related to employment decisions within the group of mothers are not stable. In particular, this could be the case if the 2009 reform affected fertility behavior, since the treatment groups are defined by having at least one child. As the reform decreased the opportunity costs of having a child, it might have had a positive effect on the birth rate. However, there is little empirical evidence that fertility decisions are affected by childcare subsidies, in the short term at least (Joseph et al., 2013; Givord \& Marbot, 2015; Bick, 2016; de Mouzon, 2020). In Luxembourg, fertility indicators for the period 2004-2014 decreased over the time of the reform (Source: Human Fertility Database, 2019), suggesting no support for an impact of the reform on fertility behavior. Another concern with the DiD approach is the correct computation of the standard errors. In my estimates, the standard errors are clustered at the local level to account for cross-sectional, within-commune dependence (Bertrand et al., 2004). By clustering at this level, I account for correlations within locality and I assume that the standard errors are not correlated across communes within regions. ${ }^{6}$

\section{Results}

\subsection{Event-type study results}

To check the plausibility of the parallel trend assumption, I take advantage of having five years before and four years after the policy change to perform an event-type study with yearly indicators (along the same lines as de Mouzon, 2020). I split the sample between treated mothers and control mothers, and regress the mother's likelihood of being in work by using a series of year dummies, a dummy for whether the mother is in the treated group, and year dummies interacted with the treatment dummy. Figure 2 a shows the coefficient and the confidence intervals of the yearly indicators interacted with the treatment dummy. The yearly indicators for the treatment group are not significantly different from zero. I also perform the same analysis for the hours of work (including the zeros). Along the intensive margin of work decision, the common trend assumption in the years prior to the reform seems to hold (Fig. 2b). I obtain the same results using the alternative control group, for example, women living without a child (Fig. 3a, b). I also perform this exercise using the three alternative treatment groups of mothers respectively: mothers with a youngest child of 0-2 years old, mothers with a youngest child of 3-6 years old, and mothers with a

\footnotetext{
6 There were 102 communes in Luxembourg in 2018.
} 
a

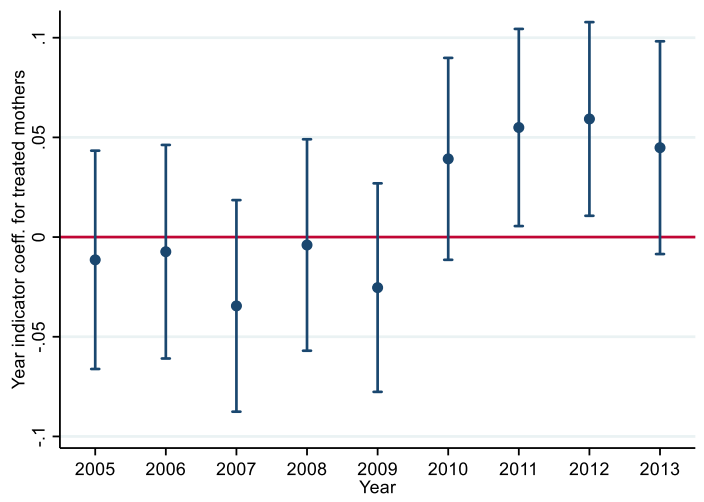

b

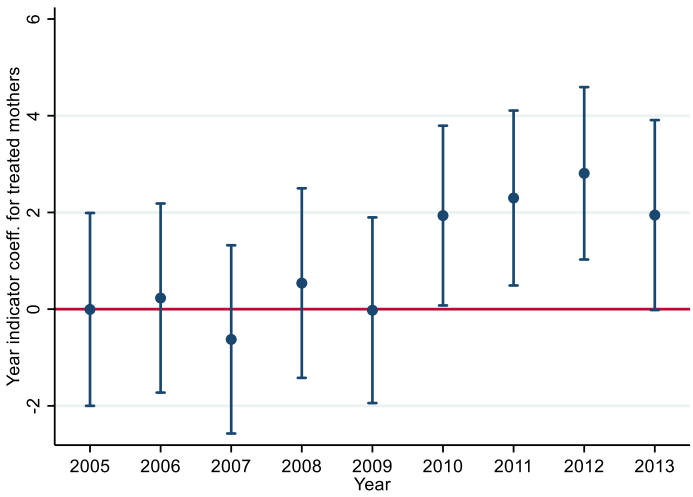

Fig. 2 Common trend for treatment and control groups. Treatment group $=$ mothers with a youngest child of 0-12 years old, control group $=$ women with a youngest child of 13 or above. a Employment. Regressing employment on yearly dummies, a treatment dummy, and their interactions reported here. b Hours of work. Regressing hours of work on yearly dummies, a treatment dummy, and their interactions reported here

youngest child of 7-12 years old (see Figs. 5-7 in the appendix). With regard to the employment equation, the yearly indicators for the treatment groups are not significantly different from zero. I obtain the same results for the hours of work equation. The results do not change when using women living without a child as an alternative control group (see Figs. 8-10 in the appendix).

To conclude based on these event-type studies, the common trend assumption seems to generally hold: the pre-reform trends in employment and hours of work for treated and control groups of mothers appear similar before the reform.

\subsection{Difference-in-differences results}

The previous section provides descriptive statistics showing that mothers with a youngest child of under 13 years of age were more likely to work, or to work for 
a

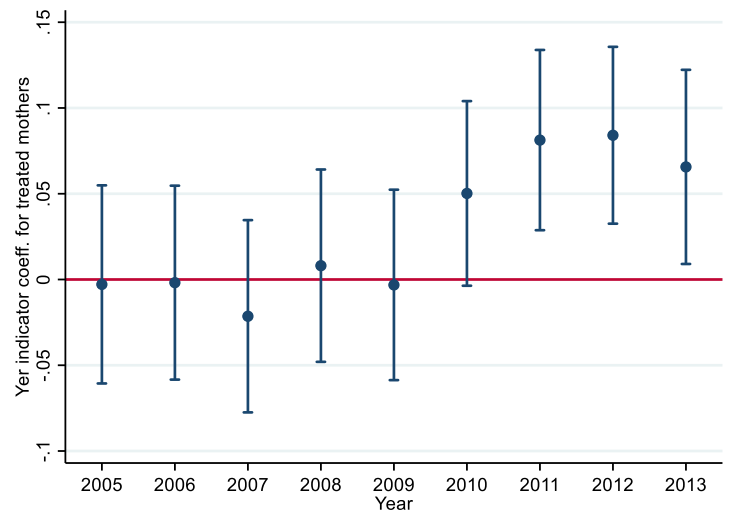

b

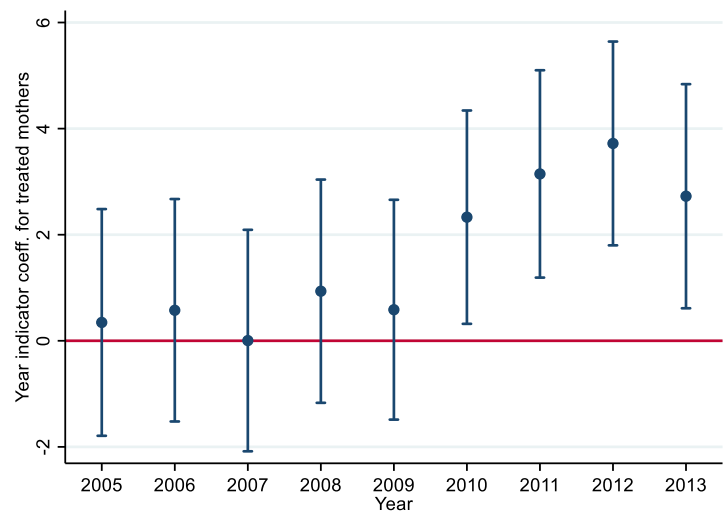

Fig. 3 Common trend for treatment and control groups. Treatment group $=$ mothers with a youngest child of 0-12 years old, control group = women living without a child. a Employment. Regressing employment on yearly dummies, a treatment dummy, and their interactions reported here. b Hours of work. Regressing hours of work on yearly dummies, a treatment dummy, and their interactions reported here

more hours, after the childcare voucher reform. Next, I use a linear probability model $^{7}$ with robust standard errors to estimate the model described in Eq. (1). In order to investigate heterogeneous response to the policy change, I complement this analysis by using different treatment groups. As alternative treatment groups, I use mothers with a youngest child of $0-2$ years old, mothers with a youngest child of 3-5 years old, and mothers with a youngest child of 6-12 years old. Mothers with a youngest child of 13-18 years old and women without a child may be good control groups for a difference-in-differences analysis of labor supply, as the pre-reform trends in employment and hours of work are shown to be similar for these groups.

\footnotetext{
7 Although the employment variable is dichotomous, I use a linear probability model that can be easily estimated using OLS, rather than a logit or probit model. In this way, the DiD coefficient (interaction term) is readily interpretable, whereas it would be much more complicated if using logit or probit.
} 
Table 3 Results of the reform on maternal employment

12

2

Panel A: Control group = mothers with a youngest child of 13-18 years old

Employment

$\begin{array}{llll}\text { Treatment effect } & 0.06^{* *}(0.01) & 0.04 * *(0.01) & 0.03 * *(0.01) \\ R^{2} & 0.03 & 0.31 & 0.31 \\ \text { Work hours } & & & \\ \text { Treatment effect } & 2.26 * * *(0.40) & 1.49 * *(0.36) & 0.97 * *(0.35) \\ R^{2} & 0.02 & 0.33 & 0.33 \\ N & 34,287 & 33,834 & 33,834\end{array}$

Panel B: Control group $=$ women living without a child

Employment

$\begin{array}{llll}\text { Treatment effect } & 0.06 * * *(0.01) & 0.04 * * *(0.01) & 0.05 * * *(0.01) \\ R^{2} & 0.02 & 0.38 & 0.38 \\ \text { Work hours } & & \\ \text { Treatment effect } & 2.02 * * *(0.47) & 1.43 * *(0.42) & 1.31 * *(0.42) \\ R^{2} & 0.02 & 0.40 & 0.41 \\ N & 26,320 & 26,016 & 26,016\end{array}$

Treatment group $=$ mothers whose youngest child is $0-12$ years old. The treatment effect is $\beta_{1}$ in Eq. (1). 1 . Baseline, 2. with extra controls (age, education, migration background, number of children) model, 3 . with a series of year dummies. Robust standard errors are in parentheses

Statistical significance is indicated by $* * * p<0.01 ; * * p<0.05 ; * p<0.1$

\subsubsection{Effect on maternal labor supply outcomes: employment and hours of work}

Table 3 shows the results of the difference-in-differences estimates for employment and hours of work when the treated group comprises mothers with a youngest child of 0-2 years old. The treatment effect is the coefficient $\beta_{1}$ from Eq. (1), and indicates the effect of the childcare voucher on mothers whose youngest child was 0-2 years old after the implementation of the reform. The first panel in Table 3 presents the effect of the reform when mothers with a youngest child of 0-12 years old are compared with those with a youngest child of 13-18 years old. Panel B shows the effect of the childcare reform when the control group is women living without a child. While some recent literature reports no effect of the expansion of childcare services on maternal employment (for the USA: Fitzpatrick, 2010; for Norway: Havnes \& Mogstad, 2011a, b; for Japan: Asai et al., 2015), the effect of the childcare reform in Luxembourg appears as positive and significant in all specifications. The employment rate of mothers with a youngest child of under 13 years old increased by 3 percentage points after the reform. The magnitude of this effect falls within a similar range to those found in studies on the role of the expansion of subsidized childcare in the Netherlands (Bettendorf et al., 2015) and in Spain (Nollenberger \& Rodriguez-Planas, 2015).

Next, I look at the effect of the reform on the hours of work. To avoid change in the sample composition, I estimate a linear model with the same sample of mothers used in the employment equation. In other words, I estimate Eq. (1) with y being the 
number of hours of work, which can potentially be zero. I again find a positive and significant effect of the childcare voucher reform on the number of hours of work. In response to the reform, women with a youngest child of under 13 years old increased their hours of work by around $1 \mathrm{~h}$ per week after the reform; in other words, approximately half a day per month. ${ }^{8}$

The policy change seems to have led mothers to work or to work for more hours, suggesting little scope for a potential crowding out effects of the new subsidized places.

\subsubsection{Effect on paternal labor supply outcomes: employment and hours of work}

The reform positively affected mothers' employment and hours of work. I now investigate whether the reform similarly affected the employment outcomes of fathers. ${ }^{9}$ I estimate the model from Eq. (1), where $y_{i}$ is taken as, respectively, the employment probability of fathers and their hours of work (including zero hours). The treatment group is fathers with a youngest child of 0-12 years old. The control group is fathers with a youngest child of 13-18 years old, as the trends in employment outcomes were similar before the childcare reform. The probability of being employed decreased with the policy change, suggesting within-couple adjustments of labor supply. Nevertheless, once I control for socio-economic characteristics and a time trend, the effect of the reform becomes non-significant. This result is in line with related previous literature (Bettendorf et al., 2015; Andresen \& Havnes, 2018; de Muizon, 2020). There is in fact little empirical evidence to support within-couple adjustments of labor supply, given that estimates of own and crosslabor elasticities of married men are close to zero (Bargain et al., 2014). Similarly, I find no effect of the reform on the hours of work of fathers.

\subsubsection{Intensity of the treatment effect}

Next, I exploit the difference in the intensity of policy change between children's age over time, as the increase in the number of subsidized places at childcare facilities was more pronounced for younger children than for older children. I re-estimate the difference-in-differences model described in Eq. (1), using alternative treatment groups: mothers with a youngest child of 0-2 years old, mothers with a youngest child of 3-5 years old, and mothers with a youngest child of 6-12 years old. The first group concerns children who are not yet at school and who need to be cared for, at least, all the time their parents are working. The two other groups comprise children of school age. The lack of out of school care for school-aged children may also be a constraint on maternal employment, as the school day is usually shorter than a standard working day and school holidays over the year may be long.

The policy had an impact along both the extensive and the intensive margins of mothers' labor supply, with stronger effects found for mothers with a youngest child of $0-2$ or 3-5 years old (see Tables 4-6). This is not surprising, as these two groups were much more constrained by the lack of available places than the other group. In

\footnotetext{
8 The legal definition of full-time work is $40 \mathrm{~h} /$ week in Luxembourg.

9 Results are available from the author on request.
} 
Table 4 Results of the reform on maternal employment

\begin{tabular}{|c|c|c|c|}
\hline & 1 & 2 & 3 \\
\hline \multicolumn{4}{|c|}{ Panel A: Control group = mothers with a youngest child of 13-18 years old } \\
\hline \multicolumn{4}{|l|}{ Employment } \\
\hline Treatment effect & $0.05(0.03)$ & $0.04 * *(0.01)$ & $0.05 * *(0.01)$ \\
\hline$R^{2}$ & 0.02 & 0.33 & 0.33 \\
\hline \multicolumn{4}{|l|}{ Work hours } \\
\hline Treatment effect & $2.91 * * *(0.75)$ & $1.93 * *(0.73)$ & $2.01 * *(0.73)$ \\
\hline$R^{2}$ & 0.06 & 0.35 & 0.36 \\
\hline$N$ & 34,287 & 33,834 & 33,834 \\
\hline \multicolumn{4}{|c|}{ Panel B: Control group $=$ women living without a child } \\
\hline \multicolumn{4}{|l|}{ Employment } \\
\hline Treatment effect & $0.07 * * *(0.03)$ & $0.06^{* * *}(0.01)$ & $0.06 * * *(0.02)$ \\
\hline$R^{2}$ & 0.02 & 0.38 & 0.38 \\
\hline \multicolumn{4}{|l|}{ Work hours } \\
\hline Treatment effect & $3.53 * * *(0.77)$ & $2.58 * *(0.74)$ & $2.62 * *(0.74)$ \\
\hline$R^{2}$ & 0.01 & 0.40 & 0.41 \\
\hline$N$ & 26,320 & 26,016 & 26,016 \\
\hline
\end{tabular}

Treatment group $=$ mothers with a youngest child of $0-2$ years old. The treatment effect is $\beta_{1}$ in Eq. (1). 1 . Baseline model, 2. with extra controls (age, education, migration background, number of children), 3 . with a series of year dummies. Robust standard errors are in parentheses

Statistical significance is indicated by $* * * p<0.01, * * p<0.05, * p<0.1$

Table 5 Results of the reform on maternal employment

\begin{tabular}{|c|c|c|c|}
\hline & 1 & 2 & 3 \\
\hline \multicolumn{4}{|c|}{ Panel A: Control group $=$ mothers with a youngest child of 13-18 years old } \\
\hline \multicolumn{4}{|l|}{ Employment } \\
\hline Treatment effect & $0.08 * * *(0.02)$ & $0.06 * *(0.02)$ & $0.06 * *(0.02)$ \\
\hline$R^{2}$ & 0.02 & 0.36 & 0.33 \\
\hline \multicolumn{4}{|l|}{ Work hours } \\
\hline Treatment effect & $3.31 * * *(0.71)$ & $2.46 * *(0.66)$ & $2.55 * *(0.66)$ \\
\hline$R^{2}$ & 0.06 & 0.39 & 0.39 \\
\hline$N$ & 32,435 & 31,978 & 31,978 \\
\hline \multicolumn{4}{|c|}{ Panel B: Control group = women living without a child } \\
\hline \multicolumn{4}{|l|}{ Employment } \\
\hline Treatment effect & $0.10 * * *(0.02)$ & $0.07 * * *(0.02)$ & $0.08 * * *(0.02)$ \\
\hline$R^{2}$ & 0.02 & 0.43 & 0.38 \\
\hline \multicolumn{4}{|l|}{ Work hours } \\
\hline Treatment effect & $3.80 * * *(1.03)$ & $2.44 * *(1.00)$ & $2.49 * *(0.97)$ \\
\hline$R^{2}$ & 0.01 & 0.34 & 0.35 \\
\hline$N$ & 24,129 & 23,836 & 23,836 \\
\hline
\end{tabular}

Treatment group $=$ mothers with a youngest child of 3-5 years old. The treatment effect is $\beta_{1}$ in Eq. (1). 1 . Baseline model, 2. with extra controls (age, education, migration background, number of children), 3 . with a series of year dummies. Robust standard errors are in parentheses

Statistical significance is indicated by $* * * p<0.01 ; * * p<0.05 ; * p<0.1$ 
Table 6 Results of the reform on maternal employment

\begin{tabular}{|c|c|c|c|}
\hline & 1 & 2 & 3 \\
\hline \multicolumn{4}{|c|}{ Panel A: Control group = mothers with a youngest child of 13-18 years old } \\
\hline \multicolumn{4}{|l|}{ Employment } \\
\hline Treatment effect & $0.05 * *(0.02)$ & $0.02(0.01)$ & $0.02(0.14)$ \\
\hline$R^{2}$ & 0.02 & 0.35 & 0.33 \\
\hline \multicolumn{4}{|l|}{ Work hours } \\
\hline Treatment effect & $2.51 * * *(0.56)$ & $1.27 * *(0.52)$ & $1.30 * *(0.52)$ \\
\hline$R^{2}$ & 0.01 & 0.38 & 0.39 \\
\hline$N$ & 32435 & 31,978 & 31,978 \\
\hline \multicolumn{4}{|c|}{ Panel B: Control group $=$ women living without a child } \\
\hline \multicolumn{4}{|l|}{ Employment } \\
\hline Treatment effect & $0.10 * * *(0.02)$ & $0.07 * * *(0.02)$ & $0.08 * * *(0.02)$ \\
\hline$R^{2}$ & 0.02 & 0.43 & 0.43 \\
\hline \multicolumn{4}{|l|}{ Work hours } \\
\hline Treatment effect & $3.80 * * *(1.03)$ & $2.44 * *(1.00)$ & $2.49 * *(0.97)$ \\
\hline$R^{2}$ & 0.01 & 0.34 & 0.35 \\
\hline$N$ & 30,787 & 30,342 & 30,342 \\
\hline
\end{tabular}

Treatment group $=$ mothers with a youngest child of 6-12 years old. The treatment effect is $\beta_{1}$ in Eq. (1). 1. Baseline model, 2. with extra controls (age, education, migration background, number of children), 3. with a series of year dummies. Robust standard errors are in parentheses

Statistical significance is indicated by $* * * p<0.01, * * p<0.05, * p<0.1$

particular, the employment opportunities of mothers with a youngest child of 0-2 years old increased by 5 percentage points after the reform. They are also found to have worked more hours after the policy introduction (by approximately $2 \mathrm{~h}$ per week). The employment probability of mothers with a youngest child of 3-5 years old increased by 6 percentage points after the reform, and they are also found to have worked for more hours (by approximately $3 \mathrm{~h}$ per week). For mothers with a youngest child of 6-12 years old, the effect of the reform is also found to be positive on employment decisions and hours of work. Their employment probability increased by 2 percentage points after the reform, and their hours of work increased by $1 \mathrm{~h}$ per week. These results are in line with previous literature on the role of the availability of before-school and after-school care on the employment of mothers with school-aged children (Felfe et al., 2015; Graves, 2013; Takaku, 2019). However, compared with what has been found by previous authors, the magnitude of the effect is lower in Luxembourg. One explanation may be that the reform in Luxembourg expanded an existing system of childcare places, rather than creating a new one. Before the reform, parents already used the system, suggesting relatively limited scope for improvement.

\subsection{Childcare arrangements after the reform}

In addition to information related to employment and hours of work, the EU-SILC survey also collects data on childcare arrangements for each child below 13 years old 
living in the household (including the type of childcare and the intensity of care). I use this information to study the extent to which making formal childcare more affordable increases its use, and whether the policy change leads to a crowding out effect (informal care being substituted by formal care). New, subsidized places may have little, if any, effect on maternal employment if the new policy results in a reduction in informal childcare provided by family members. For all children under 13 years of age, the survey collects information on the type of childcare (childcare center, childminder, informal care provided outside the household, or childcare provided by a member of the household). If non-parental childcare is used, either formal or informal care (such as that provided by grandparents or relatives), parents report the number of weekly hours of this type of care. I use this information to build dummy variables for whether a household uses a childcare center, childminder, or informal care for child $i$. Unfortunately, there is no distinction between public and private childcare centers in the survey. Nevertheless, I can distinguish between different types of non-maternal care, which will allow me to examine potential crowding out effects of the newly subsidized places. In particular, I am interested in the use of non-maternal care and the intensity of this usage measured in hours per week. In line with procedures in previous literature, I focus attention on the youngest child in the household. Figure 4 shows how childcare choices evolved over the period for mothers with a youngest child of under 13 years of age. Figure 4 a shows how childcare center attendance evolved between 2004 and 2014. Attendance increased between 2004 and 2009. After 2009 , it increased steadily for the group of mothers with children aged 3-5, and flattened out after 2012. Figure $4 \mathrm{~b}$ shows the evolution of the hours of childcare center use (including zeros) between 2004 and 2014. Up to 2009, the number of hours spent in childcare centers increased slowly in each group. After this point, the hours for childcare center use by mothers with a youngest child of 0-2 years old and of 3-5 years old increased up to 2012 and flattened out after this point. This increase was stronger for the group with youngest child aged 0-2 years old. By contrast, the hours spent in childcare centers for older children increased slightly after 2008, suggesting that the reform may have influenced the extensive margin of attendance for this group.

As a first attempt to check if the 2009 reform crowded out prior childcare arrangements, I run a simple difference regression among mothers of young children. As only parents of young children need childcare, there is no obvious control group. I thus select mothers with a youngest child of 0-12 years old, and run the following regression for each mother:

$$
\operatorname{Pr}\left(\text { Work }_{i} \& \text { Childcare }_{i j}\right)=\alpha+\gamma \text { Post }_{i}+\beta X_{i}+\varepsilon_{i}
$$

where Work $_{i}$ is a dummy equal to 1 if the mother $i$ is working, Childcare Cij $_{j}$ is the childcare mode $j$ used by mother $i$ for her youngest child (childcare center, childminder, or informal care). Post $t_{i}$ is a dummy equal to 1 in the post-reform period and $X_{i}$ is a vector of controls (education, age of the mother, a set of dummies for the mother's migration background, gross household income except mothers' earnings, and a dummy for the mother being a single mother), and $\gamma$ is the coefficient of interest for the policy impact. Table 7 presents the estimates of $\gamma$. For all mothers, the probability of using a childcare center increased significantly after the reform, 
a. Childcare attendance

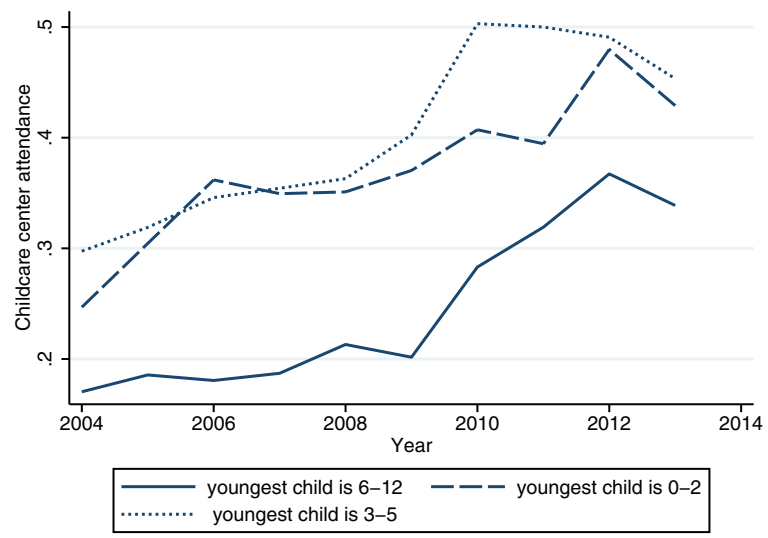

b. Hours of childcare

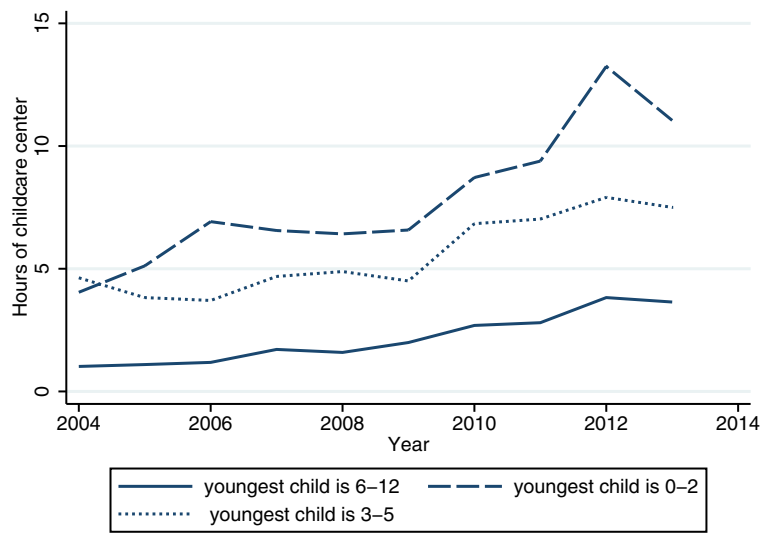

Fig. 4 Childcare attendance and hours of childcare before and after the childcare reform, by age of children. Source: EU-SILC-PSELL 3. Statistics are weighted using individual weights

independent of their work situation. Previous literature suggests that newly available places may crowd out existing private places (Havnes \& Mogstad, 2011a), informal arrangements (Takaku, 2019), or comparable public childcare arrangements (Fitzpatrick, 2010). The 2009 reform substantially decreased the price of formal childcare, making it relatively more attractive than it had previously been. The extent to which the policy change led to non-desirable crowding out effect depends on how much informal and formal care are substitutes. Estimates show that for all mothers, the probability of using informal care while working increased after the reform. Nonsignificant changes in the propensity to use a childminder while working are found, except for mothers with a youngest child of $0-2$ years old. The probability of using a childcare center and that of using informal care increased after the reform, suggesting that these types of care are complementary. These results suggest little support for a crowding out effect of the new policy. 
Table 7 Results of the multinomial model of employment and childcare choices, post vs. pre-reform

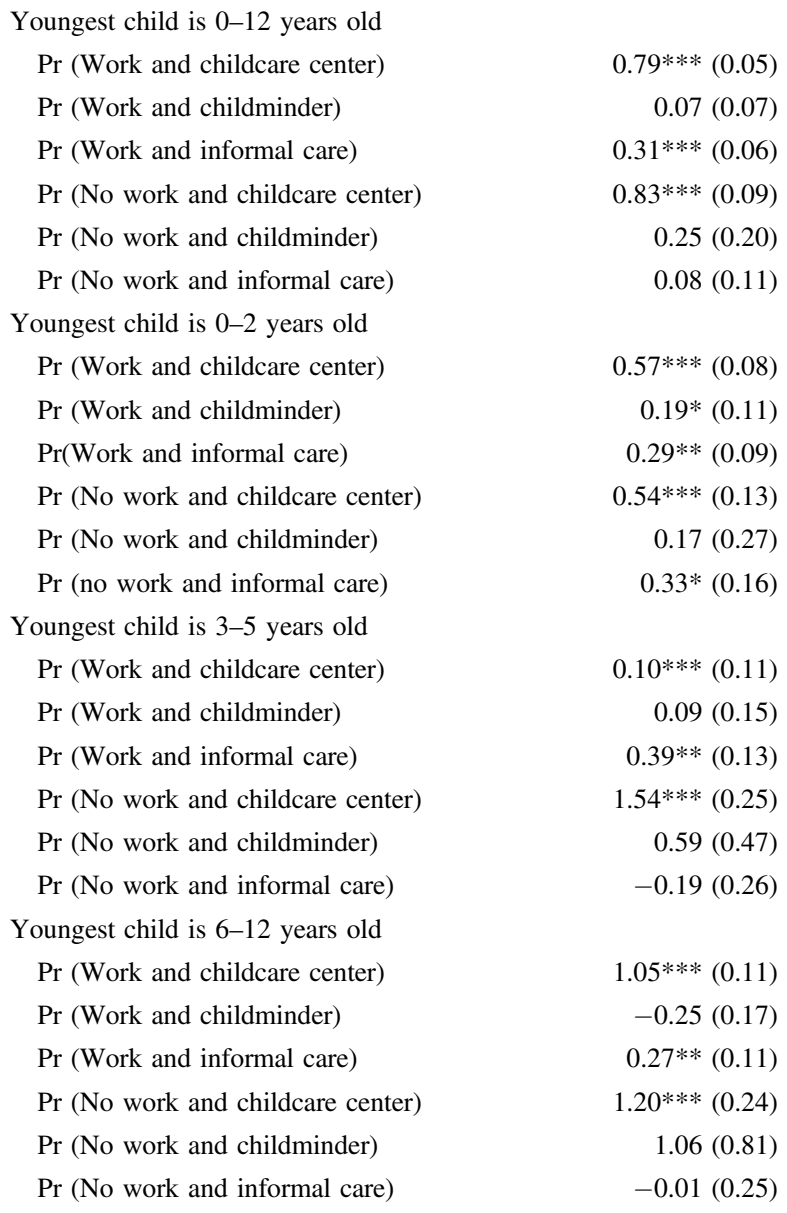

Ref.: "No work and maternal care". Controls include education, age of the mother, the mother's migration background, gross household income except mothers' earnings, and a dummy for single mothers

Significance levels reported at $* 10 \%$ level; **5\% level; ***1\% level

\subsection{Sensitivity analysis}

The main threat to my identification strategy consists of deviations from a common trend between the treatment and the control groups in the years preceding the actual treatment. In the previous section, I perform event-type studies to provide support for the common trend assumption. Next, I provide additional support for the validity of the key identification strategy of my model: that the treatment and the controls follow the same time trend over the period, even though they have different characteristics.

To accomplish this, I start by estimating a placebo effect: I shift the introduction of the policy to 4 years prior to the 2009 reform. Table 10 in the appendix shows the results for the alternative treatment groups and the control groups. The placebo 
effects from these models are non-significant, confirming that there were no systematic differences between the treatment and the control groups of mothers before the 2009 reform. In addition, I test whether the slopes of the outcome are different across the treated and control groups over time, by interacting the treatment variable with year dummies (Pischke, 2005). In Eq. (1), I include the interactions of the year dummies and the treatment dummy for the first four pre-treatment years (for the years 2004-2007). The interaction for the last year of the pre-reform period is excluded from the model to avoid the dummy trap. The coefficients of these interaction terms should be non-significant if the outcome trends between the treatment and control groups are similar. Table 11 in the appendix presents the results of the test of the difference-in-differences assumption. While none of the year-treatment coefficients is significantly different from zero, one can conclude that the difference-indifferences does not vary significantly between the two groups in the pre-treatment period. The same test for the alternative treatment groups yields similar results.

\subsection{Heterogeneity of effect for subgroups}

To this point, I have assumed that the effects of the reform on childcare arrangements and maternal employment are homogeneous. I now explore whether the effects of the reform are heterogeneous across different groups of mothers. Providing estimates of heterogeneous effects is important, given the likely heterogeneity in gains from selecting into childcare and into the labor market (Cornelissen et al., 2016; Kottelenberg \& Lehrer, 2017). For example, for women who were not working before the reform, the reduction of childcare costs induced by the reform lowered the reservation wage, thus a positive effect of the reform on labor market participation may be expected. For women who were already working before the reform, the effect will depend on the number of hours of work.

Providing estimates of heterogeneous effects is also important for policymakers, since early childhood education and care policies are often used as instruments to reduce inequalities between children. Providing access to affordable childcare services may support maternal employment, increase a family's income, and thus contribute to reducing the risk of poverty. With regard to childcare outcomes, the most vulnerable parents (low educated, low income, or non-native) may have less knowledge of the institutional rules to allocate available places among applicants. They may also have poorer access to available information about waiting lists and less support from a network to press for being better ranked on a waiting list. Descriptive evidence indicates that the most vulnerable parents make less use of websites giving relevant information about childcare providers, and that they rarely subscribe to multiple waiting lists to enhance their chances of success (Vanderbroeck, 2010). Investigating the effects of the childcare policy on vulnerable subgroups of families is thus highly relevant. Accordingly, I look at the heterogeneous response to the reform for the following subgroups: non-native mothers, lowereducated mothers, and single mothers.

To test for heterogeneity in treatment effects across subgroups, I use the baseline model, but I now allow the coefficient of the treatment effect to vary for subgroups of mothers (Abadie, 2005). The subgroups are defined by prior employment status, education level, migration background, and marital status. In further regressions, I 
thus estimate the following model:

$$
\begin{aligned}
Y_{i t}=\alpha & +\beta_{1}\left(\text { Treat }_{i} \times \text { Post }_{t}\right)+\beta_{2} \text { Treat }_{i}+\beta_{3} \text { Post }_{t} \\
& +\beta_{4} G_{i}+\beta_{5}\left(G \times \text { Treat }_{i}\right)+\beta_{6}\left(G \times \text { Post }_{t}\right) \\
& +\beta_{7}\left(G \times \text { Treat }_{i} \times \text { Post }_{t}\right)+\varepsilon_{i t}
\end{aligned}
$$

where $G_{i}$ is a dummy that defines the subgroup of mothers. The coefficient $\beta_{7}$ on the triple interaction between the dummy for the subgroup of mothers, the treatment dummy, and the post-reform dummy indicate whether mothers in a particular subgroup react systematically differently to the childcare reform compared with the overall sample of mothers. Table 8 shows the results where the treatment group is mothers with a youngest child of aged 0-12 and the control group is mothers with a youngest child of 13 years old or above.

Heterogeneous effects by initial employment status I start by evaluating whether the reform generated different responses in line with mothers' initial employment status. It is probable that the overall effect found in the previous section masks different responses according to labor market participation and working hours before the reform. I therefore define a dummy variable for whether a mother was in work before the reform. Panel A of Table 8 shows the results of the heterogeneous effect of the reform, by previous employment status. While the employment response to the reform is the same irrespective of the previous employment status, the effect on hours of work is much more important for mothers who were already working before the reform than for the overall sample. The hours worked by mothers who were in employment before the reform increased subsequently by almost $4 \mathrm{~h}$ per weekroughly double the estimates found for the overall group of treated mothers. To complement these results, I also look at different responses referring to the hours of work before the reform. I define a dummy variable for whether a mother was in parttime work before the reform (fewer than $30 \mathrm{~h}$ per week), meaning the sample is thus restricted to working mothers before the reform. Panel B of Table 8 shows the estimates for a heterogeneous effect of the reform on hours of work by prior part-time employment. I find slightly larger effects for mothers working part-time before the reform. These results suggest that the overall increase of maternal employment was the result of mothers' entering the labor market as well as by an increase of working hours among mothers who were in employment.

Heterogeneous effects by education level, migration background, and marital status of mothers I also analyze whether the reform led to different responses in line with the education level of mothers. Lower-educated mothers may have restricted access to subsidized childcare in the case of rationing, for example because their knowledge about the process of place allocation is limited. If so, they could be more responsive to an increase in the number of subsidized places than their average counterpart. To examine this, I define a dummy equal to 1 for education lower than secondary-school level. The estimates are reported in Panel C of Table 8, and show no evidence of a heterogeneous response by mothers' education level. I next look at heterogeneous responses to the childcare reform by migration background. I define a dummy variable for whether a mother is non-native. Panel D of Table 8 shows the results, and again I do not find support for a heterogeneous response on the employment probability and the hours of work in this regard. Lastly, I investigate 
Table 8 Results of heterogeneous effects

\begin{tabular}{|c|c|c|}
\hline & Employment & Work hours \\
\hline \multicolumn{3}{|l|}{ Panel A: prior employment } \\
\hline Treatment effect & $0.07 * *(0.02)$ & $1.34 *(0.66)$ \\
\hline $\begin{array}{l}\text { Treatment effect*prior } \\
\text { employment }\end{array}$ & $0.00(0.02)$ & $2.57 *(0.08)$ \\
\hline$P$ value & 0.000 & 0.001 \\
\hline$R^{2}$ & 0.58 & 0.53 \\
\hline \multicolumn{3}{|l|}{ Panel B: prior part time } \\
\hline Treatment effect & $0.04 * *(0.13)$ & $1.47 *(0.55)$ \\
\hline $\begin{array}{l}\text { Treatment effect* } * \text { prior } \\
\text { part time }\end{array}$ & $0.15(0.25)$ & $2.11 *(0.99)$ \\
\hline$P$ value & 0.000 & 0.000 \\
\hline$R^{2}$ & 0.03 & 0.01 \\
\hline \multicolumn{3}{|l|}{ Panel C: education } \\
\hline Treatment effect & $0.07 * * *(0.01)$ & $2.58 * * *(0.51)$ \\
\hline Treatment effect*low educated & $-0.01(0.02)$ & $-0.39(0.79)$ \\
\hline$P$ value & 0.001 & 0.000 \\
\hline$R^{2}$ & 0.09 & 0.08 \\
\hline \multicolumn{3}{|l|}{ Panel D: marital status } \\
\hline Treatment effect & $0.04 * *(0.01)$ & $1.38 * *(0.54)$ \\
\hline Treatment effect* single mother & $-0.03(0.03)$ & $0.38(1.21)$ \\
\hline$P$ value & 0.777 & 0.111 \\
\hline$R^{2}$ & 0.02 & 0.04 \\
\hline \multicolumn{3}{|l|}{ Panel E: migration background } \\
\hline Treatment effect & $0.08 * * *(0.02)$ & $3.20 * * *(0.56)$ \\
\hline Treatment effect*non-native & $0.03(0.02)$ & $0.49(0.94)$ \\
\hline$P$ value & 0.000 & 0.000 \\
\hline$R^{2}$ & 0.06 & 0.04 \\
\hline
\end{tabular}

Control group $=$ mothers with a youngest child of 13 years old or above. Robust s.e. in parentheses

Statistical significance is indicated by $* * * p<0.01 ; * * p<0.05 ; * p<$ 0.1

whether the reform led to different responses with respect to mothers' marital status (see Panel E of Table 8). Similar to the other observations, there is no evidence of a heterogeneous response regarding the employment probability and the hours of work. The absence of any significant change may reflect that the scope for improvement was limited for single mothers, as before the 2009 reform they already benefitted from high subsidies and priority places in the public childcare sector. This may explain why single mothers were not affected by the reform to a notably greater extent than other mothers.

To sum up, there is evidence of heterogeneous response by prior employment status, but I find no support for a heterogeneous response on the employment probability and the hours of work by education, migration background, or marital status. 


\section{Conclusion}

This paper has focused on the impact on maternal employment in Luxembourg as a result of the expansion of access to subsidized childcare. The country represents a context where childcare is universal and heavily subsidized, but bound by capacity constraints. I took advantage of a large reform, which substantially increased the number of subsidized childcare places, to provide additional empirical evidence on the matter. I show that the employment of mothers with a youngest child under 13 years old increased by 4 to 7 percentage points in response to the reform, while their hours of work on average increased by around 2-3 h per week. These aggregate effects hide difference between children's ages, as mothers of the youngest children are found to be more responsive to the reform than mothers of children in primary education. The magnitude of the effects falls within a similar range to those found in comparable studies, except for mothers of children in primary school, whose estimates are found to be lower than in other countries. It is likely that because the reform in Luxembourg expanded an existing system of before-school and after-school places, rather than creating a new scheme, there was limited scope for improvement. Studying heterogeneous effects reveals a differential impact by prior employment status, showing that the overall increase of maternal employment results from mothers entering the labor market, as well as by an increase of hours worked among working mothers.

This paper contributes to existing literature on childcare policy in two ways. The first is by providing empirical evidence concerning the effect of expanding access to subsidized childcare. This is especially relevant at a time when the closure of childcare providers to most families during the COVID-19 crisis has shed light on the crucial role of access to childcare; both to support paid work and for children's development. The second contribution is that while most previous evidence relies on programs that make childcare subsidies conditional on employment and income, the current paper analyzes the effect of a policy change on the overall population, as well on specific subgroups.

In Luxembourg, as in most OECD countries, there are both public and for-profit childcare providers. The two types are likely to be heterogeneous in terms of quality, opening days, opening hours, and location, making it highly relevant to account for heterogeneity in the provision of childcare when analyzing the effects of childcare policy on the outcomes for children and parents. Moreover, there is little evidence on the effect of government provision in and regulation of the early childhood care sector on the supply side; for example, on workers and companies in the childcare sector. At a time when most OECD countries provide public support to the childcare sector, the extent to which this support will be needed going forward depends on how the childcare market adjusts (Blanden et al., 2020).

Acknowledgements This research is part of the CHILDCARE project "Optimal policies in the market for childcare: theory and evidence from Luxembourg," supported by the National Research Fund, Luxembourg (contract FNR/C14/SC/8337045). I would like to thank Andrea Albanese, Michela Bia, Arnaud Dupuy, Alessio Fusco, Peter Shirley, and Konstantinos Tatsiramos for their valuable comments, as well as participants at various seminars and conferences for helpful discussions. I am particularly grateful to two anonymous referees and the editor-in-chief and co-editor of the journal for their constructive comments and suggestions. All errors and omissions remain my own. 


\section{Compliance with ethical standards}

Conflict of interest The author declares no competing interests.

Publisher's note Springer Nature remains neutral with regard to jurisdictional claims in published maps and institutional affiliations.

\section{Appendix}

Figures 5-10.

Tables 9-11.

a. Employment

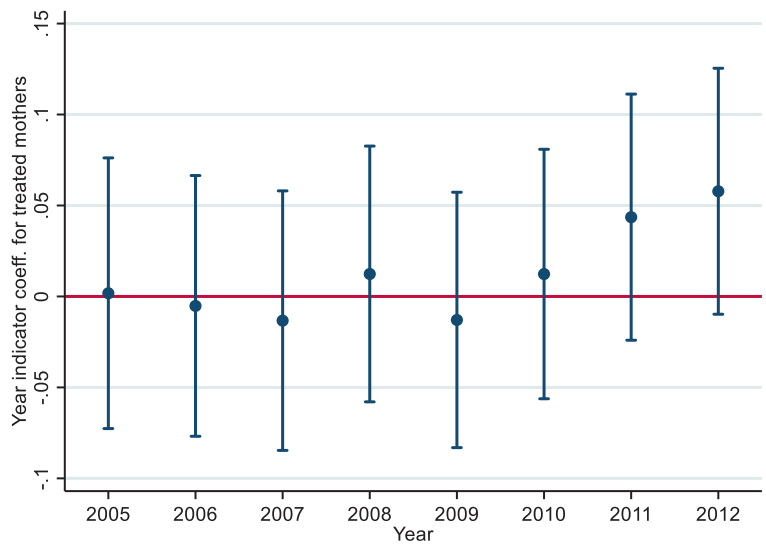

b. Hours of work

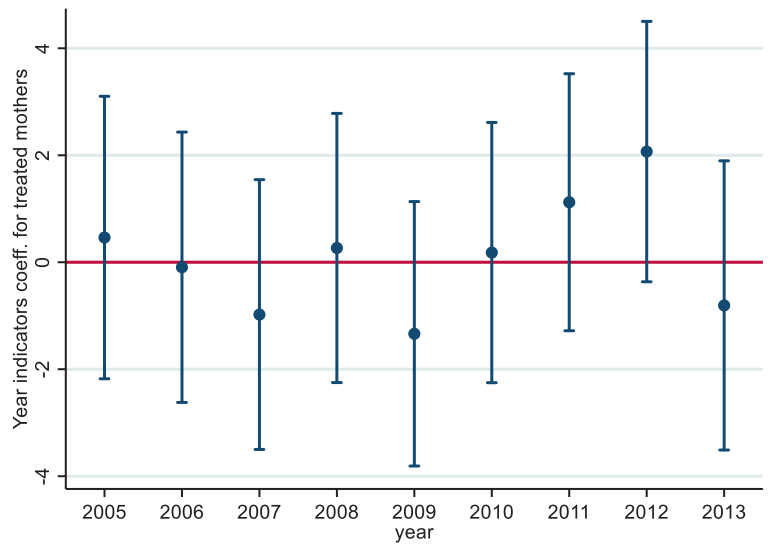

Fig. 5 Common trend for treatment and control groups. Treatment group $=$ mothers with a youngest child of $0-2$ years old, control group $=$ women with a youngest child of 13 or above 
a. Employment

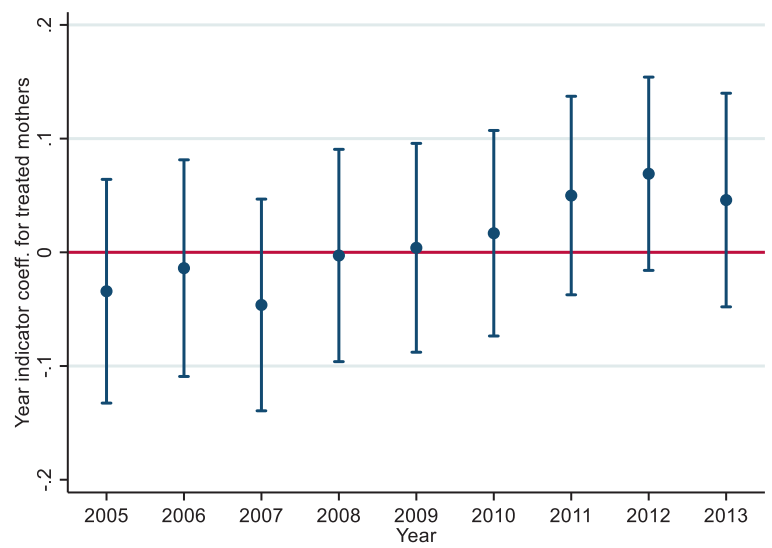

b. Hours of work

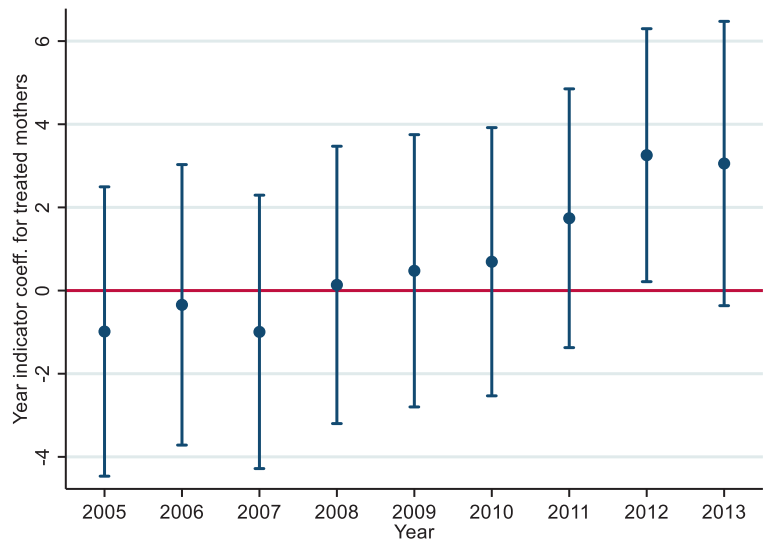

Fig. 6 Common trend for treatment and control groups. Treatment group $=$ mothers with a youngest child of 3-5 years old, control group $=$ women with a youngest child of 13 or above 
a. Employment

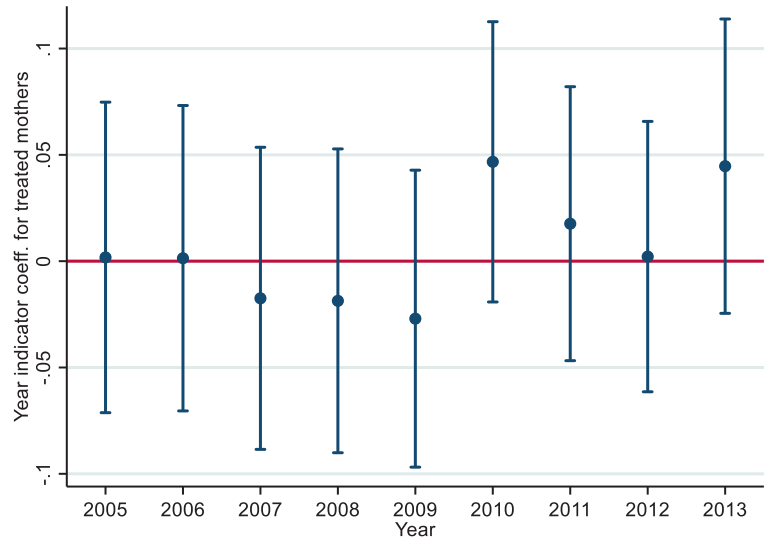

b. Hours of work

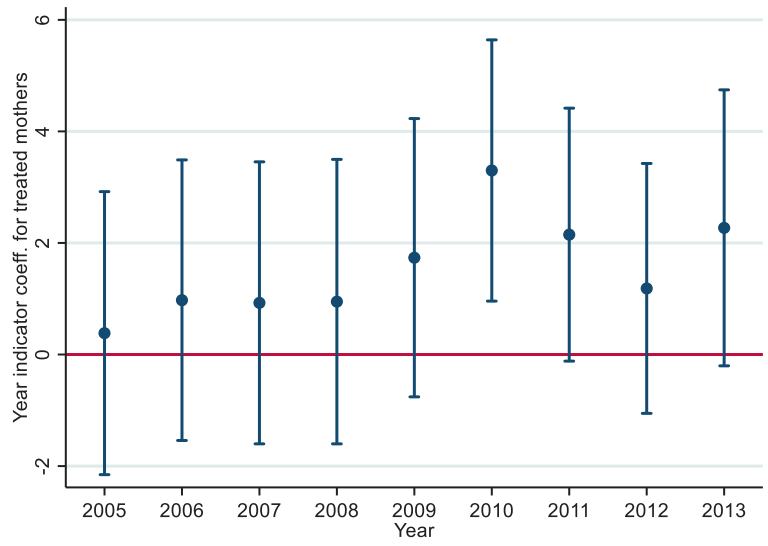

Fig. 7 Common trend for treatment and control groups. Treatment group $=$ mothers with a youngest child of 7-12 years old, control group $=$ women with a youngest child of 13 or above 
a. Employment

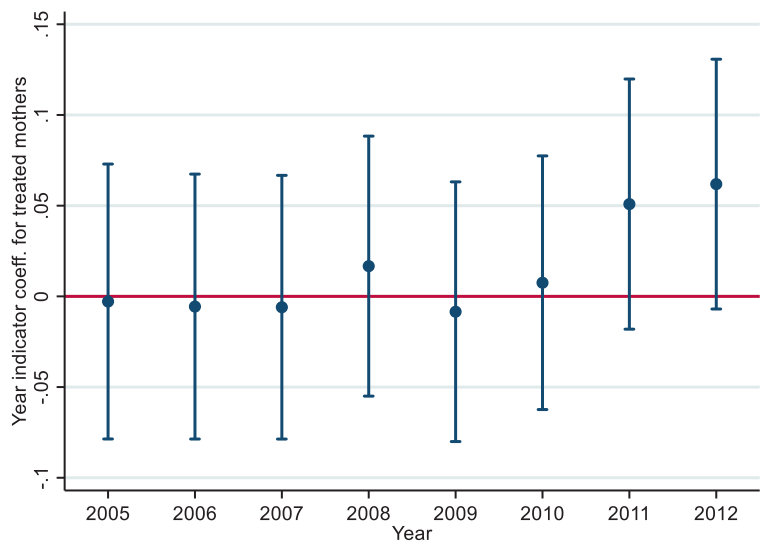

b. Hours of work

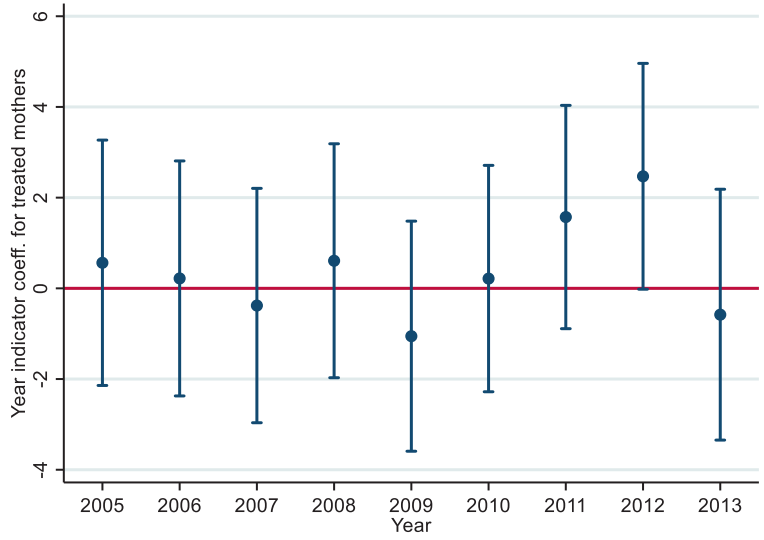

Fig. 8 Common trend for treatment and control groups. Treatment group $=$ mothers with a youngest child of $0-2$ years old, control group $=$ women without a child 
a. Employment

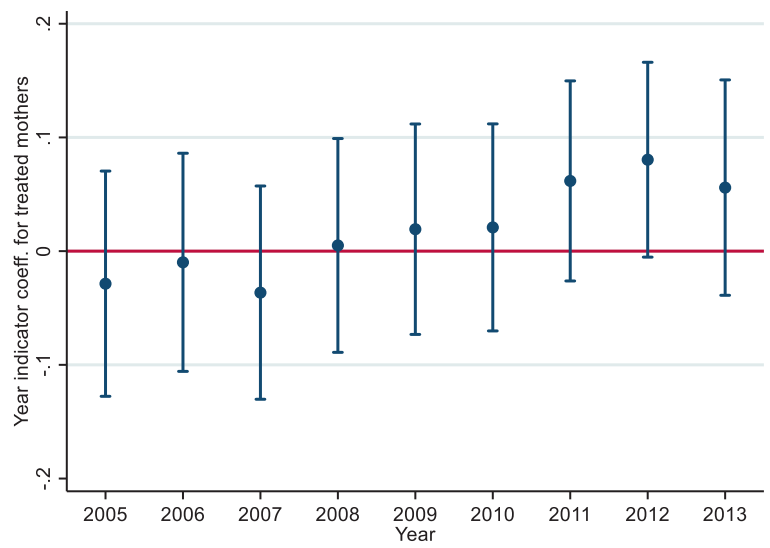

b. Hours of work

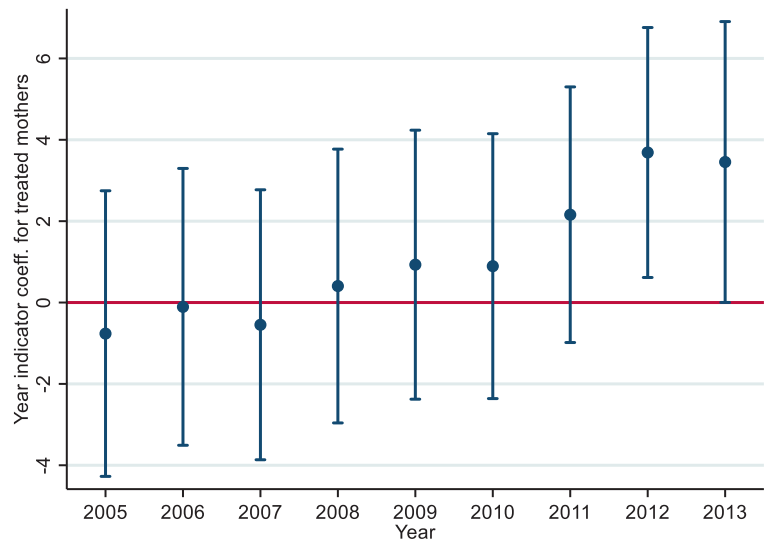

Fig. 9 Common trend for treatment and control groups. Treatment group $=$ mothers with a youngest child of 3-5 years old, control group $=$ women without a child 
a. Employment

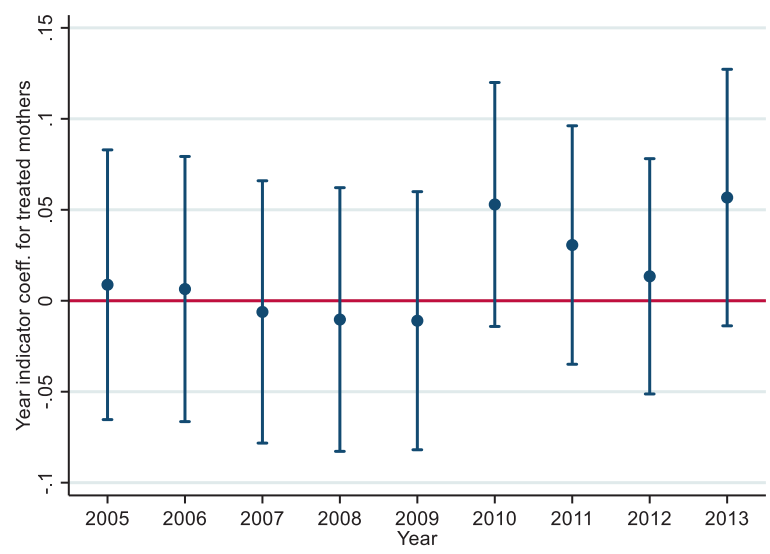

b. Hours of work

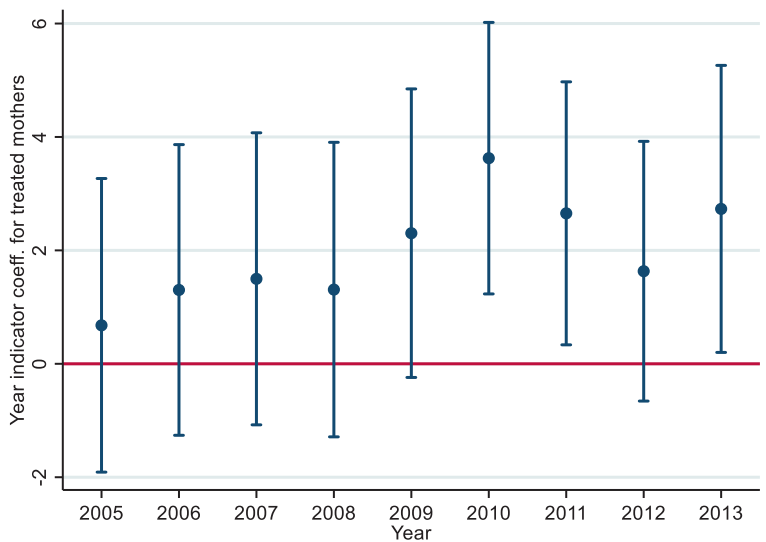

Fig. 10 Common trend for treatment and control groups. Treatment group $=$ mothers with a youngest child of 7-12 years old, control group = women without a child 
Table 9 Summary statistics for mothers with a youngest child of 0-12 years old, and mothers with a youngest child of 13 years old or above before and after the 2009 childcare reform

\begin{tabular}{|c|c|c|c|}
\hline & Before & After & Difference \\
\hline \multicolumn{4}{|c|}{ Mothers with a youngest child of $0-12$ years old } \\
\hline Employed & 0.60 & 0.66 & $0.06^{* * *}$ \\
\hline Weekly hours of work (incl. zeros) & 17.65 & 19.70 & $2.05^{* *}$ \\
\hline Part-time employment & 0.49 & 0.52 & $0.03 * *$ \\
\hline Household income $^{a}$ & 5000 & 5996 & $996^{* * *}$ \\
\hline Lone mother & 0.10 & 0.11 & 0.01 \\
\hline Age & 35 & 36 & $1 * * *$ \\
\hline \multicolumn{4}{|l|}{ Education: } \\
\hline - Primary & 0.40 & 0.37 & 0.03 \\
\hline - Secondary & 0.30 & 0.33 & 0.03 \\
\hline - High school & 0.30 & 0.30 & 0.00 \\
\hline \multicolumn{4}{|l|}{ Migration background: } \\
\hline - Native & 0.55 & 0.50 & $0.05^{* *}$ \\
\hline - Migrant arrived when child & 0.34 & 0.37 & $0.03 *$ \\
\hline - Migrant arrived when adult & 0.11 & 0.13 & 0.02 \\
\hline No. of children & 1.94 & 1.98 & $0.04 *$ \\
\hline Age of the partner & 38 & 39 & 1 \\
\hline Partner works & 0.91 & 0.90 & 0.01 \\
\hline \multicolumn{4}{|l|}{ Youngest child is 13 years old or above } \\
\hline Employed & 0.73 & 0.77 & $0.04 * *$ \\
\hline Weekly hours of work (incl. zeros) & 24.37 & 25.14 & $0.77 *$ \\
\hline Part-time employment & 0.28 & 0.35 & $0.07 * * *$ \\
\hline Household income $^{a}$ & 4889 & 5965 & $1076^{* * * *}$ \\
\hline Lone mother & 0.06 & 0.07 & 0.01 \\
\hline Age & 41 & 43 & $2 * * *$ \\
\hline \multicolumn{4}{|l|}{ Education: } \\
\hline - Primary & 0.35 & 0.35 & 0.00 \\
\hline - Secondary & 0.33 & 0.36 & $0.03 * *$ \\
\hline - High school & 0.23 & 0.29 & $-0.03 * *$ \\
\hline \multicolumn{4}{|l|}{ Migration background: } \\
\hline - Native & 0.52 & 0.58 & $0.06 * *$ \\
\hline - Migrant arrived when child & 0.38 & 0.30 & $-0.08^{*}$ \\
\hline - Migrant arrived when adult & 0.10 & 0.10 & 0.00 \\
\hline No. of children & 1.47 & 1.45 & -0.02 \\
\hline Age of the partner & 47 & 48 & 1 \\
\hline Partner works & 0.73 & 0.71 & $0.02 *$ \\
\hline
\end{tabular}

Source: EU-SILC/PSELL3. Statistics are weighted using individual weights

ahousehold income is the gross household income, except mother's earnings from the labor market, in euros per month. The before period is the years 2004-2008. The after period is the years 2010-2014

Statistical significance is indicated by $* p<0.1 ; * * p<0.05 ; * * *<0.01$ 
Table 10 Results of placebo reform on maternal employment and work hours

Treatment group $=$ mothers with a youngest child of $0-12$ years old

\begin{tabular}{|c|c|c|c|c|c|c|}
\hline \multicolumn{4}{|l|}{ Panel A } & \multicolumn{3}{|l|}{ Panel B } \\
\hline Employment & 0.03 & 0.03 & 0.03 & & & \\
\hline \multirow[t]{2}{*}{ Placebo reform } & $(0.03)$ & $(0.02)$ & $(0.17)$ & 0.03 & 0.04 & 0.04 \\
\hline & 0.07 & 0.31 & 0.31 & $(0.02)$ & $(0.03)$ & $(0.03)$ \\
\hline \multicolumn{2}{|l|}{$R^{2}$} & & & 0.07 & 0.32 & 0.30 \\
\hline \multicolumn{7}{|l|}{ Work hours } \\
\hline \multirow[t]{2}{*}{ Placebo reform } & 1.73 & 1.40 & 1.43 & 1.74 & 1.42 & 1.40 \\
\hline & $(0.88)$ & $(0.92)$ & $(0.92)$ & $(0.80)$ & $(0.73)$ & $(0.73)$ \\
\hline$R^{2}$ & 0.02 & 0.33 & 0.33 & 0.05 & 0.18 & 0.18 \\
\hline$N$ & 34,287 & 33,834 & 33,834 & 26,320 & 26,016 & 26,016 \\
\hline \multicolumn{7}{|c|}{ Treatment group $=$ mothers with a youngest child of $0-2$ years old } \\
\hline \multirow{3}{*}{$\begin{array}{l}\text { Employment } \\
\text { Placebo reform }\end{array}$} & 0.03 & 0.04 & 0.04 & & & \\
\hline & $(0.03)$ & $(0.03)$ & $(0.03)$ & 0.03 & 0.04 & 0.04 \\
\hline & 0.07 & 0.32 & 0.30 & $(0.03)$ & $(0.03)$ & $(0.03)$ \\
\hline \multicolumn{2}{|l|}{$R^{2}$} & & & 0.07 & 0.32 & 0.30 \\
\hline \multicolumn{7}{|l|}{ Work hours } \\
\hline \multirow[t]{2}{*}{ Placebo reform } & 1.09 & 1.42 & 1.52 & 1.09 & 1.42 & 1.52 \\
\hline & $(0.27)$ & $(0.92)$ & $(0.93)$ & $(0.27)$ & $(0.92)$ & $(0.93)$ \\
\hline$R^{2}$ & 0.05 & 0.36 & 0.13 & 0.05 & 0.36 & 0.13 \\
\hline$N$ & 34,287 & 33,834 & 33,834 & 26,320 & 26,016 & 26,016 \\
\hline \multicolumn{7}{|c|}{ Treatment group $=$ mothers with a youngest child of 3-5 years old } \\
\hline \multicolumn{7}{|l|}{ Employment } \\
\hline \multirow[t]{2}{*}{ Placebo reform } & 0.03 & 0.02 & 0.02 & 0.05 & 0.04 & 0.04 \\
\hline & $(0.37)$ & $(0.04)$ & $(0.04)$ & $(0.04)$ & $(0.04)$ & $(0.04)$ \\
\hline$R^{2}$ & 0.02 & 0.36 & 0.37 & 0.03 & 0.43 & 0.30 \\
\hline \multicolumn{7}{|l|}{ Work hours } \\
\hline \multirow[t]{2}{*}{ Placebo reform } & 1.92 & 1.41 & 1.42 & 2.09 & 0.48 & 0.46 \\
\hline & (1.33) & $(1.22)$ & $(1.22)$ & $(1.86)$ & (1.75) & $(1.75)$ \\
\hline$R^{2}$ & 0.01 & 0.39 & 0.39 & 0.01 & 0.35 & 0.35 \\
\hline$N$ & 32,435 & 31,978 & 31,978 & 24,129 & 23,836 & 23,836 \\
\hline \multicolumn{7}{|c|}{ Treatment group $=$ mothers with a youngest child of 6-12 years old } \\
\hline \multicolumn{7}{|l|}{ Employment } \\
\hline \multirow[t]{2}{*}{ Placebo reform } & 0.03 & 0.01 & 0.00 & 0.05 & 0.02 & 0.02 \\
\hline & $(0.02)$ & $(0.06)$ & $(0.01)$ & $(0.37)$ & $(0.03)$ & $(0.25)$ \\
\hline$R^{2}$ & 0.02 & 0.36 & 0.37 & 0.03 & 0.43 & 0.30 \\
\hline \multicolumn{7}{|l|}{ Work hours } \\
\hline \multirow[t]{2}{*}{ Placebo reform } & $2.27 * *$ & $1.16^{*}$ & $1.17^{*}$ & 0.78 & 0.39 & 0.39 \\
\hline & $(0.61)$ & $(0.05)$ & $(0.03)$ & $(1.40)$ & $(1.31)$ & $(1.31)$ \\
\hline$R^{2}$ & 0.01 & 0.39 & 0.39 & 0.01 & 0.35 & 0.35 \\
\hline$N$ & 32,435 & 31,978 & 31,978 & 24,129 & 23,836 & 23,836 \\
\hline
\end{tabular}

Panel A: control group $=$ women with a youngest child of 13 years old or above. Panel B: control group $=$ women living without a child. Placebo reform: 2005: baseline year; 2007: placebo post-treatment year. 1. Baseline model, 2. with extra controls (age, education, nationality, no. of children), 3. with a series of year dummies. Robust standard errors are in parentheses

Statistical significance is indicated by $* * * p<0.01 ; * * p<0.05 ; * p<0.1$ 
Table 11 Results of testing differences in slope's outcomes in the pre-reform period

\begin{tabular}{|c|c|c|c|c|}
\hline & Employment & Hours of work & Employment & Hours of work \\
\hline & Panel A & & Panel B & \\
\hline \multicolumn{5}{|c|}{ Treatment group $=$ mothers with a youngest child of $0-12$ years old } \\
\hline Treatment effect*2004 & $-0.01(0.02)$ & $-1.38(0.80)$ & $-0.02(0.02)$ & $-1.72(0.90)$ \\
\hline Treatment effect*2005 & $0.01(0.02)$ & $-0.14(0.78)$ & $0.00(0.02)$ & $-0.50(0.80)$ \\
\hline Treatment effect*2006 & $0.02(0.21)$ & $0.33(0.75)$ & $0.01(0.21)$ & $-0.01(0.77)$ \\
\hline Treatment effect*2007 & $0.03(0.02)$ & $0.67(0.75)$ & $0.02(0.02)$ & $0.33(0.77)$ \\
\hline \multicolumn{5}{|c|}{ Treatment group $=$ mothers with a youngest child of 0-2 years old } \\
\hline Treatment effect*2004 & $-0.03(0.03)$ & $-1.3(1.49)$ & $-0.06(0.05)$ & $0.07(2.24)$ \\
\hline Treatment effect $* 2005$ & $0.01(0.03)$ & $-0.46(1.47)$ & $-0.06(0.04)$ & $-0.74(2.01)$ \\
\hline Treatment effect*2006 & $0.01(0.03)$ & $0.12(1.47)$ & $-0.04(0.04)$ & $-1.84(1.94)$ \\
\hline Treatment effect*2007 & $0.03(0.03)$ & $0.20(1.41)$ & $-0.04(0.04)$ & $0.45(1.93)$ \\
\hline \multicolumn{5}{|c|}{ Treatment group $=$ mothers with a youngest child of 3-5 years old } \\
\hline Treatment effect*2004 & $-0.04(0.05)$ & $-2.25(1.60)$ & $-0.06(0.05)$ & $0.07(2.24)$ \\
\hline Treatment effect*2005 & $-0.04(0.04)$ & $-1.98(1.53)$ & $-0.06(0.04)$ & $-0.74(2.01)$ \\
\hline Treatment effect*2006 & $-0.02(0.04)$ & $-1.29(1.47)$ & $-0.04(0.04)$ & $-1.84(1.94)$ \\
\hline Treatment effect*2007 & $0.03(0.04)$ & $-1.01(1.42)$ & $-0.04(0.04)$ & $0.45(1.93)$ \\
\hline \multicolumn{5}{|c|}{ Treatment group $=$ mothers with a youngest child of 6-12 years old } \\
\hline Treatment effect*2004 & $-0.02(0.03)$ & $-3.36(1.17)$ & $-0.04(0.03)$ & $-1.45(1.77)$ \\
\hline Treatment effect*2005 & $0.01(0.03)$ & $-1.88(1.19)$ & $-0.01(0.03)$ & $-0.64(1.80)$ \\
\hline Treatment effect*2006 & $0.02(0.03)$ & $-1.12(1.19)$ & $0.00(0.03)$ & $0.24(1.80)$ \\
\hline Treatment effect*2007 & $0.02(0.03)$ & $-0.39(1.19)$ & $0.00(0.03)$ & $1.62(1.85)$ \\
\hline
\end{tabular}

Panel A: control group = women with a youngest child of 13 years old or above. Panel B: control group $=$ women living without a child. Robust standard errors are in parentheses

Statistical significance is indicated by $* * * p<0.01 ; * * p<0.05 ; * p<0.1$

\section{References}

Abadie, A. (2005). Semiparametric difference-in-differences estimators. Review of Economic Studies, 72 (1), 1-19.

Adda, J., Dustmann, C., \& Stevens, K. (2017). The career costs of children. Journal of Political Economy, 125(2), 293-337.

Almond, D., \& Currie, J. (2011). Human capital development before age five. In Handbook of labor economics, (vol. 2, pp. 1315-1486). Elsevier.

Andresen, M., \& Havnes, T. (2018). Child care, parental labor supply and tax revenue. IZA Discussion Papers 11576, Institute of Labor Economics (IZA).

Angelov, N., Johansson, P., \& Lindahl, E. (2016). Parenthood and the gender gap in pay. Journal of Labor Economics, 34(3), 545-579.

Angrist, J., \& Pischke, J.S. (2009). Mostly harmless econometrics: an empiricist's companion. Princeton University Press.

Asai, Y., Ryo, K. \& Shintaro, Y. (2015). Childcare availability, household structure, and maternal employment. Journal of the Japanese and International Economies, 38, 172-192.

Baker, M., Gruber, J., \& Milligan, K. (2008). Universal child care, maternal labor supply, and family wellbeing. Journal of Political Economy, 116(4), 709-745. 
Bargain, O., Orsini, K., \& Peichl, A. (2014). Comparing labor supply elasticities in Europe and the United States: new results. Journal of Human Resources, 49(3), 723-838.

Bassok, D., Fitzpatrick, M. \& Loeb, S. (2014). Does state preschool crowd-out private provision? The impact of universal preschool on the childcare sector in Oklahoma and Georgia. Journal of Urban Economics, 83(C), 18-33.

Bauernschuster, S., Hener, T., \& Rainer, H. (2016). Children of a (policy) revolution: the introduction of universal child care and its effect on fertility. Journal of the European Economic Association, 14(4), 975-1005.

Bergstrom, T., Blume, L., \& Varian, H. (1986). On the private provision of public goods. Journal of Public Economics, 29(1), 25-49.

Berlinski, S., \& Galiani, S. (2007). The effect of a large expansion of pre-primary school facilities on preschool attendance and maternal employment. Labour Economics, 14(3), 665-680.

Bernal, R., \& Keane, M. P. (2011). Child care choices and children's cognitive achievement: the case of single mothers. Journal of Labor Economics, 29(3), 459-512.

Bertrand, M., Duflo, E., \& Mullainathan, S. (2004). How much should we trust differences-in-differences estimates? The Quarterly Journal of Economics, 119(1), 249-275.

Bick, A. (2016). The quantitative role of child care for female labor force participation and fertility. Journal of the European Economic Association, 14, 639-668.

Bettendorf, L. J., Jongen, E. L., \& Muller, P. (2015). Childcare subsidies and labour supply: evidence from a large Dutch reform. Labour Economics, 36(C), 112-123.

Blanden, J., Crawford, C., Drayton, E., Farquharson, C., Jarvie, M., \& Paull, G. (2020). Challenges for the childcare market: the implications of COVID-19 for childcare providers in England. IFS Report, Institute for Fiscal Studies, 93.

Blau, F.D., \& Winkler, A.E. (2017). Women, work, and family. NBER Working Papers, National Bureau of Economic Research, Inc.

Bousselin, A. (2015). Emploi des mères et recours à un mode de garde payant: le rôle de la proximité des services de garde d'enfants et de leur coût: Un exemple à partir de données luxembourgeoises. Economie et Prévision, 206-207, 91-115.

Bousselin, A. (2017). Childcare, maternal employment and residential location. LISER Working Papers 2017-05, LISER.

Bradford, D.F., \& Shaviro, D.N. (1999). The economics of vouchers. Working Paper 7092, National Bureau of Economic Research.

Brewer, M., Cattan, S., Crawford, C., \& Rabe, B. (2020). Does more free childcare help parents work more? IFS Working Paper W20/9, Institute for Fiscal Studies.

Busse, A., \& Gathmann, C. (2018). Free daycare and its effects on children and their families. IZA Discussion Papers 11269, Institute of Labor Economics (IZA).

Cascio, E. U. (2009). Maternal labor supply and the introduction of kindergartens into american public schools. Journal of Human Resources, 44, 1.

Cascio, E. U., Haider, S. J., \& Nielsen, H. S. (2015). The effectiveness of policies that promote labor force participation of women with children: a collection of national studies. Labour Economics, 36, 64-71.

Cattan, S. (2016). Universal preschool and maternal labour supply. IZA world of labor, IZA.

Collins, C., Landivar, L. C., Ruppanner, L., \& Scarborough, W. J. (2020). COVID-19 and the gender gap in work hours. Gender, Work \& Organization, 28(S1), 549-560.

Cornelissen, T., Dustmann, C., Raute, A., \& Schonberg, U. (2016). From late to MTE: alternative methods for the evaluation of policy interventions. Labour Economics, 41(C), 47-60.

Croda, E., \& Grossbard, S. (2021). Women pay the price of COVID-19 more than men. Review of Economics of the Household, 19(1), 1-9.

Cunha, F., Heckman, J.J., Lochner, L., \& Masterov, D.V. (2005). Interpreting the evidence on life cycle skill formation. NBER Working Papers, National Bureau of Economic Research, Inc Eckhoff.

Cunha, F., Heckman, J.-J., \& Schennan, S. (2010). Estimating the technology of cognitive and non cognitive skill formation. Econometrica, 78(3), 883-931.

de Muizon, M. (2020). Subsidies for parental leave and formal childcare: be careful what you wish for. Review of Economics of the Household, 18, 735-772.

Del Boca, D., Oggero, N., Profeta, P., \& Rossi, M. (2020). Women's and men's work, housework and childcare, before and during COVID-19. Review of Economics of the Household, 18, 1001-1017.

Del Boca, D., Flinn, C., \& Wiswall, M. (2014). Household choices and child development. The Review of Economic Studies, 81(1 (286)), 137-185.

European Commission (2010). Women, work, and family. Communication from the commission, European Commission. 
Felfe, C., \& Lalive, R. (2018). Does early child care affect children's development? Journal of Public Economics, 159, 33-53.

Felfe, C., Nollenberger, N., \& Rodriguez-Planas, N. (2015). Can't buy mommy's love? Universal childcare and children's long-term cognitive development. Journal of Population Economics, 28(2), 393-422.

Fitzenberger, B., Sommerfeld, K., \& Steffes, S. (2013). Causal effects on employment after first birth: a dynamic treatment approach. Labour Economics, 25(C), 49-62.

Fitzpatrick, M. D. (2010). Preschoolers enrolled and mothers at work? The effects of universal prekindergarten. Journal of Labor Economics, 28(1), 51-85.

Fitzpatrick, M. D. (2012). Revising our thinking about the relationship between maternal labor supply and preschool. Journal of Human Resources, 47(3), 583-612.

Fort, M., Ichino, A. \& Zanella, G. (2016). Cognitive and non-cognitive costs of daycare 0-2 for girls. IZA Discussion Paper 9756.

Gelbach, J. B. (2002). Public schooling for young children and maternal labor supply. American Economic Review, 92(1), 307-322.

Givord, P., \& Marbot, C. (2015). Does the cost of child care affect female labor market participation? An evaluation of a French reform of childcare subsidies. Labour Economics, 36(C), 99-111.

Goldin, C. (2014). A grand gender convergence: Its last chapter. American Economic Review, 14, 1091-1119.

Goux, D., \& Maurin, E. (2010). Public school availability for two-year olds and mothers' labour supply. Labour Economics, 17(6), 951-962.

Graves, J. (2013). School calendars, child care availability and maternal employment. Journal of Urban Economics, 78, 57-70.

Gromada, A., Richardsoni, D., \& Rees, G. (2020). Childcare in a global crisis: the impact of COVID-19 on work and family life. Innocenti Research Brief, 2020-18, UNICEF Office of Research-Innocenti, 11.

Hardoy, I., \& Pal, S. (2015). Enticing even higher female labor supply: the impact of cheaper day care. Review of Economic of the Household, 13(4), 815-836.

Havnes, T., \& Mogstad, M. (2011a). Money for nothing? Universal child care and maternal employment. Journal of Public Economics, 95(11-12), 1455-1465.

Havnes, T., \& Mogstad, M. (2011b). No child left behind: subsidized child care and children's long-run outcomes. American Economic Journal: Economic Policy, 3(2), 97-129.

Herbst, C. M. (2017). Universal child care, maternal employment, and children's long-run out- comes: evidence from the US Lanham act of 1940. Journal of Labor Economics, 35(2), 519-564.

Human Fertility Database (2019). Max Planck Institute for Demographic Research (Germany) and Vienna Institute of Demography (Austria). www.humanfertility.org. (data downloaded June, 2019).

Joseph, O., Pailhé, A., Recotillet, I., \& Solaz, A. (2013). The economic impact of taking short parental leave: evaluation of a French reform. Labour Economics, 25, 63-75.

Journal Officiel G-D Luxembourg (2009). Memorial a26: règlement grand-ducal du 13 février 2009 instituant le chèque-service accueil.

Keane, M. (1995). A new idea for welfare reform. Quarterly Review, 19(2), 2-17.

Kottelenberg, M. J., \& Lehrer, S. F. (2017). Targeted or universal coverage? Assessing heterogeneity in the effects of universal child care. Journal of Labor Economics, 35(3), 609-653.

Lefebvre, P., \& Merrigan, P. (2008). Child-care policy and the labor supply of mothers with young children: a natural experiment from Canada. Journal of Labor Economics, 26(3), 519-548.

Lefebvre, P., Merrigan, P., \& Verstraete, M. (2009). Dynamic labour supply effects of child care subsidies: evidence from a canadian natural experiment on low-fee universal child care. Labour Economics, 16, 490-502.

Leibowitz, A., Waite, L., \& Witsberger, C. (1988). Child care for preschoolers: differences by child's age. Demography, 25, 205-220.

Lundberg, S., \& Rose, E. (2000). Parenthood and the earnings of married men and women. Labour Economics, 7(6), 689-710.

Lundin, D., Mork, E., \& Ockert, B. (2008). How far can reduced childcare prices push female labour supply? Labour Economics, 15(4), 647-659.

Matha, T.Y., Cindy, V., \& Wintr, L. (2016). Employment, wages and prices: how did firms adjust during the economic and financial crisis? Evidence from a survey of Luxembourg firms. BCL Working Papers, Central Bank of Luxembourg (BCL).

Ministry of Family (2004-2012). Annual reports. Ministry of Family, Luxembourg.

Morrissey, T. W. (2017). Child care and parent labor force participation: a review of the research literature. Review of Economics of the Household, 15(1), 1-24. 
Mueller, G., \& Plug, E. (2006). Estimating the effect of personality on male and female earnings. ILR Review, 60(1), 3-22.

Nollenberger, N., \& Rodriguez-Planas, N. (2015). Full-time universal childcare in a context of low maternal employment: modest but persistent effects. Labour Economics, 36, 124-136.

OECD (2018). Engaging young children. OECD.

OECD (2019). OECD economic survey-Japan 2019. OECD.

Pischke, J.S. (2005). Empirical methods in applied economics. Lecture notes, LES.

Rossin-Slater, M. (2018). Maternity and family leave policy. In S. L. Averett, L. M. Argys, \& S. D. Hoffman (Eds.), The Oxford handbook of women and the economic, Oxford University Press (pp. 81-100).

Sigle-Rushton, W., \& Waldfogel, J. (2007). The incomes of families with children: a cross-national comparison. Journal of European Social Policy, 17, 299-318.

Steuerle, C.E. (2000). Common issues for voucher programs. In C. E. Steuerle, V. D. Ooms, G. E. Peterson, \& R. D. Reischauer (Eds.), Vouchers and the provision of public services (pp. 3-39). Brookings Institution Press.

Takaku, R. (2019). The wall for mothers with first graders: availability of afterschool childcare and continuity of maternal labor supply in Japan. Review of Economics of the Household, 17, 177-199.

Todd, P., \& Wolpin, K. (2003). On the specification and estimation of the production function for cognitive achievement. Economic Journal, 113(485), F3-F33.

Valentova, M. (2015). How do traditional gender roles relate to social cohesion? Focus on differences between women and men. Social Indicators Research, 127, 153-178.

Valentova, M. (2019). The impact of parental leave policy on the intensity of labour-market participation of mothers: Do the number of children and pre-birth work engagement matter? Journal of European Social Policy, 29(3), 428-445.

Vanderbroeck, M. (2010). Early education and care: equity and excellence in the foundational stage. In Equity and excellence in education: towards maximal learning opportunities for all students. Routledge.

Viitanen, T. (2011). Child care voucher and labour market behaviour: experimental evidence from Finland. Applied Economics, 43(23), 3203-3212.

Waldfogel, J. (1998). Understanding the family gap in pay for women with children. Journal of Economic Perspectives, 12(1), 137-156.

Warner, M.E, \& Gradus, R. (2009). The consequences of implementing a child care voucher: evidence from Australia, The Netherlands and USA. Tinbergen Institute Discussion Papers 09-078/3, Tinbergen Institute.

Yamamura, E., \& Tsustsui, Y. (2021). The impact of closing schools on working from home during the COVID-19 pandemic: evidence using panel data from Japan. Review of Economics of Household, 19 (1), 41-60. 